1963

\title{
Geology of the unconsolidated deposits of Lake County, Indiana
}

Reuben J. Vig

University of North Dakota

How does access to this work benefit you? Let us know!

Follow this and additional works at: https://commons.und.edu/theses

Part of the Geology Commons

\section{Recommended Citation}

Vig, Reuben J., "Geology of the unconsolidated deposits of Lake County, Indiana" (1963). Theses and Dissertations. 309.

https://commons.und.edu/theses/309

This Thesis is brought to you for free and open access by the Theses, Dissertations, and Senior Projects at UND Scholarly Commons. It has been accepted for inclusion in Theses and Dissertations by an authorized administrator of UND Scholarly Commons. For more information, please contact und.commons@library.und.edu. 


\title{
CEOLCGY OF THE UNCONSOLIDATED DENOSITS, OF LAKE COUNTY, INDIANA
}

\author{
by \\ Reuben J. Vis
}

B. S. in IIning Lagineering, University of North Dakota, 1937

\author{
A Thesis \\ Subnitted to the Paculty \\ of the \\ Graduate school \\ of the \\ University of North Daketa \\ in Partial Pulfillment of the Pequirenents \\ for the Degree of \\ Master of Seience
}

Grand Porks, North Dakota

June

1.963 
$\left.1 \operatorname{lig}^{2}\right|^{2}$

This thosis subnitted by Reuben J. Vis in partial fulfulwent of the regulreants for the begree of daster of Selence in the University of North Makste, is heroby approved by the condtee under whos the work has been done.
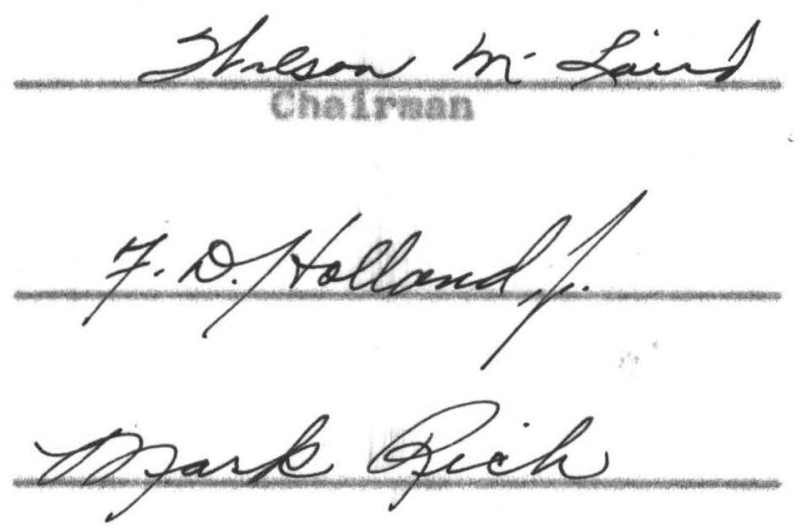

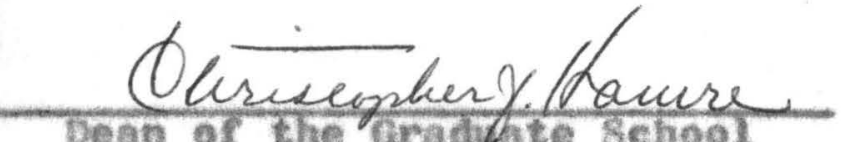




\section{CONTENTS}

Page

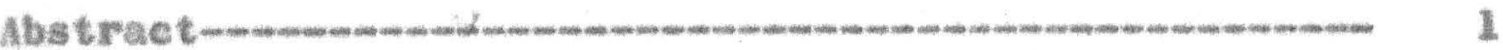

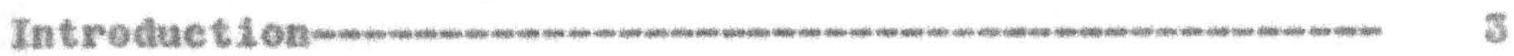

Purpose and seope-m-

Location of area-m-m- 4

Methods of Investigation-m-

Previous investigations-m-m- 6

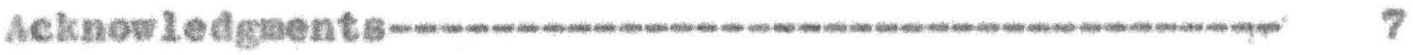

Ceography -

Phys Lography and topography-m-9

Dra Inage-10 11

CLIA $1 \mathrm{t}$ -

Leonony related to surfece featuresm-mm-m-n-m- 15

CeVlogy -

Geologhe setting-m-m-m-19

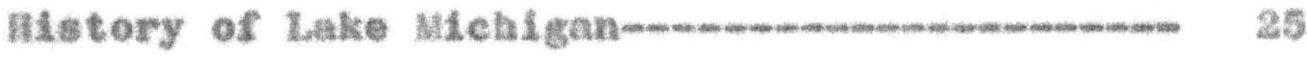

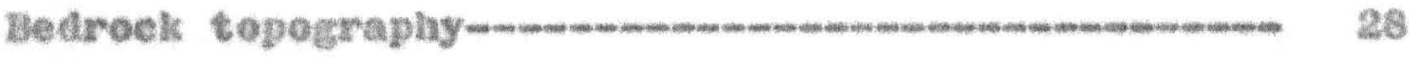

Calunet lake plain-m-31.

Burface foatures-m-m-31.

Beaches of Lake Chlcago-mm-32

Dune

Sabsurface deposits-m- 37

Valparaiso horaine-m- 39 
Geology-ment inued

Valparatso woralne--eont inaed

Surface features-m-n-m-10

Morainic lakes-m-43

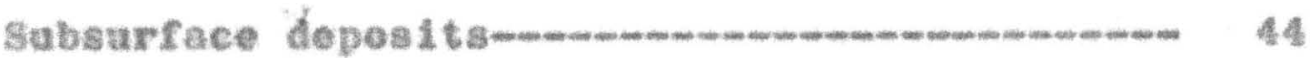

Clayey t1118-m-m-45

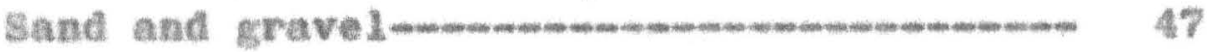

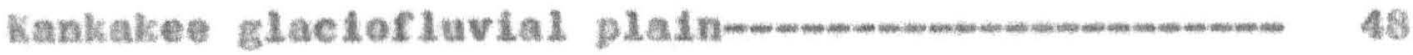

Surface featurea-m-m- 51

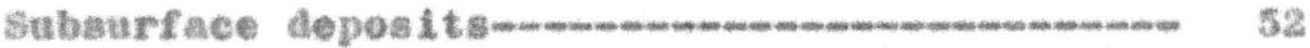

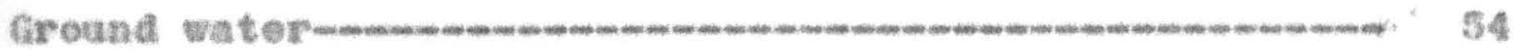

Consold the ted depos $1 \mathrm{t} s-m-m-54$

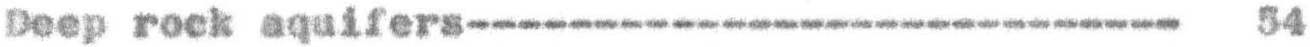

Shallow rock aguiferts-m-5 54

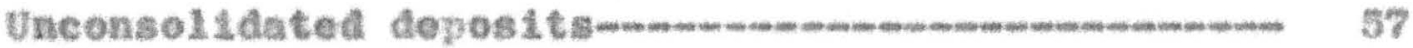

We har

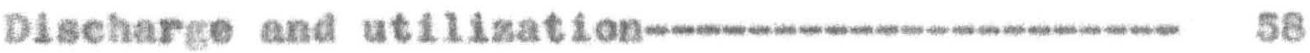

Sarface wa ter-m- 60

Suหมа

Selected bibliography-m-m-m 


\section{IINSTrear IONS}

\section{(All plates are in pocket.)}

Plate. 1. Topographic map of Lake County, Indiana

2. Surface geology of Lake County. Indlana

3. Map of Lake County, Indiana, showing contours on the bedrock surface

4. Map of Lake county, Indrana, showing locations of wells and lines of geologie sections

5. Cross sections showing generalized goology, 11 nes $A-A^{*}$ to $C-C^{*}$

6. Cross sections showing generalized geology, Iines $\mathrm{D}-\mathrm{D}^{\prime}$ to $\mathrm{E}-\mathrm{E}^{\text {? }}$

7. Cross sections showing generalized gealogy, Lines $P-p^{\prime}$ to $J-J$ '

8. Map of Lake County, Indiana, showing generalized contours on the piezometric surface

Figure 1. Diagramatic wap of Indiana, showing

Lake County and glacial boundariesm-m-

2. Diagramatic bedrock surface map of

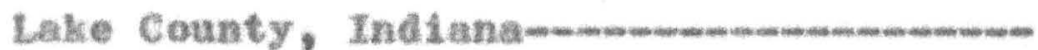


3. Ta-stratigraphic subdivision of the wisconsinan stage in the Lake Muchigan glaeial Lobe. Only part of the named moraines in Illinois are showw, and named moraines are worphostratigraphic anits. The inferred linit of glacial. ice throagh time is shown alagrammatically on a vertical scale in radiecarbon years. After Frye and

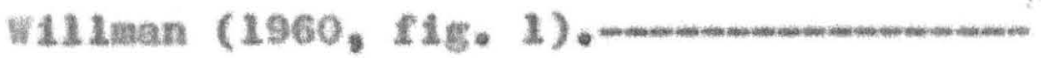

4. DLagranmatic map of Lake County, Indiana, showing bearock valleys-mon-m s0 
Table 1. Average wonthly precipitation and teaperature at Gary, Indiand, 1836-59-om- 14 2. Popalation and its distribution with respect to the physiographic divisions of Lake County, Indianam-m-17 3. Crop production in lake Coanty, Indiana, 1959 and $1954-20 m-18$ 4. Livestock production in Lake County, Indiana, 1959 and $1954-18$ 5. Selected chemical anslyses of water in Lake County, Indianam-m- Ss 


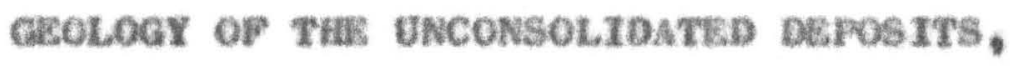

OF LAKE COUNTY, INDIANA

Reaben J. vig

AEsTract

Lake County is in the extreme northwestern corner of Indiana. The county is aivided into three physiographic unitst (1) Calumet lake plain, (2) Valparaiso moraine, (3) Kankakee glaciofluvial plain.

The Caluset lake plain was covered by glacial Lake Chicago. Beach lines show the areal extent of the various phases of the lake' $\mathrm{g}$ history. The Valparaise aoraine, a broad upland, trends east-west across the county. An end woraine on the north side of this upland is correlated with the Tinley eoraine in Illinois. The Kankakee glaeiofluvial plain, rorkerly warshland, wlopes gently frow the Valparaiso woraine to the Kankakee River.

The bedrock surface has a general slope toward the basin of Lake Mchigan. Pive former streas valleys onter the basin from a preglacial drainage divide in IIInois. Till averaging about 50 feet in thiekness, probably of IIInoian (7) age, Iles above the bedrock surface, AheetIike deposit of sand and gravel lies beneath the drift of the Valparalso moraine and crops out on the surface of the 
Kankakee glaciofluvial plain. Presumably, the sand and gravel was lald down during the retreat of the ice sheet that deposited the I11inolan (?) H11. Two distinet t11is were deposited upon thls sand and gravel. The lower is a gray-blue elayey til, which is overlain by the upper buff to yellow, slity, elay till of the Valparalso moraine. Lake Mlehigan provides water for the northern third of the county and ground water is the source of supply for the rest of the county. 


\section{INTRODUCT TON}

\section{Purpose and Scope}

Lake County, because of the strategic importance of its location, has becone one of the great industrial centers of the world. The prineipal cause for the developent of this industrial center was Lake Michigan; a barrier to east-west land traffic. At the hend of lake Michigan the highly developed railroad, highway, and water-transportation systeas interseet and come to a focus. The avallable water supply, suitable topography, and favorable conditions for expansion are inportant factora in the growth of the county. Greater growth of both Industry and population is predicted for the county due to the completion of the Great Lakes-st. Lawrence Beaway.

An investigation of the ground-water resources of a ten-county area in northwestern Indiana was begun in June 1954 by personnel of the U.8. Ceologicat Survey in cooperation with the Water Resources Division, Indiana Departwent of Conservation. Data ased in this thesis was collected as part of this ten-county area investigation and also from other published reports.

The purpose of this thesis study was to map and describe the areal geology of Lake Coanty. Special emphasis is placed upon the surface and subsurface geology of the unconsolidated deposits laid down during the pleistocene. The geologic inforwation is needed as an aid (1) in the 
proper developent of the natural resources of the county.

(2) in the sound planning of engineering works and land utiliation. and (3) in the interpretation and description of the glactal deposits of Lake County.

\section{Location of Arra}

Lalie County is in the extrene northwestern corver of Indiana (fig, 1) and mas an aroa of about 517 square wiles. It has two natural boundaries, lake dilehigan on the north and the Lankakee River on the south. The vest side adjoins the state of MIInols and on the east side is Porter county, IndLanas.

Nethods of Investigation

A geologic reconnaissance of lake County was wade by north-south and east-west traverses at approximately one 露1. Intervals. Bites visited included sand and gravel. pits, clay pits, road cuts, and sand dune areas. Geological features wero exanined, sections were weasured in $p i t s$, and spot sanples were taken for detalled study of the Mithology. Observation wells were establiahed to obtain data concerning the changes in storage of the ground-water agulferg and to deteraine the factors affecting the changes in the water level. A quality of wuter program was started to obtaln information on tho chovical quality of water from the vartous aguifers.

Well arillers were interviewed regarding the character 


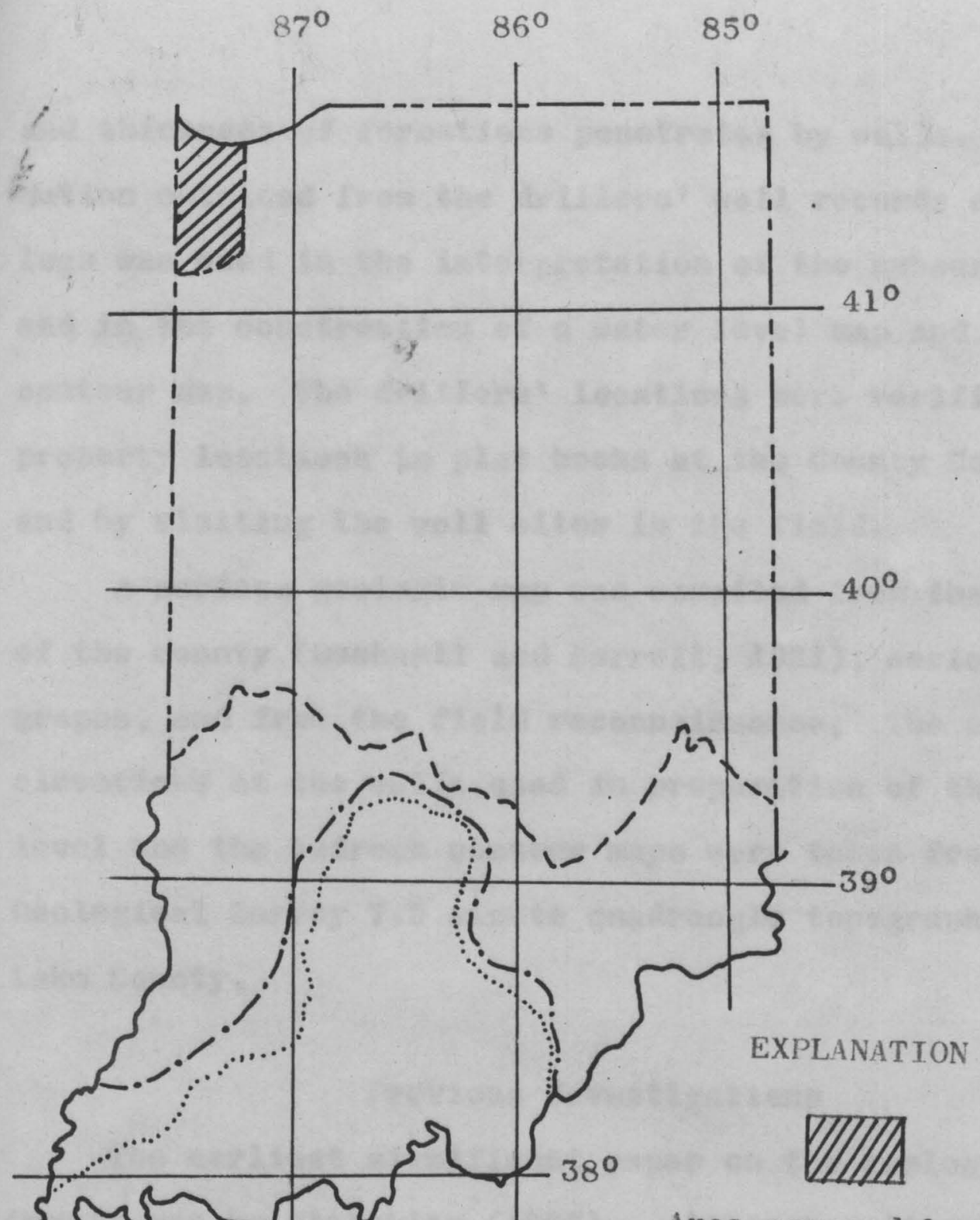

Area covered by thesis

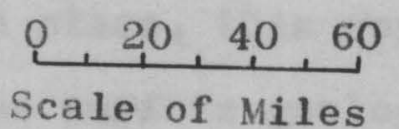

Wisconsin glacial boundary

Illinoian glacial boundary

Kansan glacial boundary

(Thornbury and Wayne, 1957)

Figure 1.--Diagrammatic map of Indiana showing Lake County and glacial boundaries. 
and thickness of rormations penetrated by wells. The information obtained frow the Arillers" well records and well logs was used in the interpretation of the subsurface geology and in the construction of a water level map and a bedrock contour aap. The abillers' locations were verified rroa property locations in plat books at the County Courthouse and by visiting the well sites in the rield.

A surface geologic wap was compiled from the solls map of the county (Bushnell and Barrel1, 1921), aerial photographs, and from the field reconnaissance. The surface elevations at the wolls used in preparation of the water level and the bedroek eontour maps were taken fros 0.8 . Ceological Survey 7.5 anute quadrangle topographic waps of Lake county.

Previous Investigations

The earliest significant paper on the geology of Lake County was by alatehley (1897). Although cultural ehanges have taken place, this report is still an excellent reference on the surface geology of the connty.

Bradiey (1870) named Lake Kankakee and outlined the probable extent of its shore 1ine. Prank Leverett (1899, 1015) wade wany contribations to the glacial and postglacial history of the north central states. Although proviously mentioned in publications by Matchley (1897) and Leverett $(1899,1915)$, reports on the dunes of northwest Indlana 
were written by Barrett (1016), Cressey (1928), and Bieber b. and smith (1952).

Hany reports have been written on the history and formation of the Creat Lakes and of Lake Chicago. Those by Breta (1951, 1955) and Wough (1958) give new theories concerning the events that occurred during the history of the creat Lakes.

\section{Acknowledgwents}

The writer expresses his appreciation to Dr. Laird, Chairwan of the Department of Geology, University of North Dakota for his general supervision and counsel. Acknow Ledgaents are also aade to Dr. P. D, Nlolland, Jr., and Dr. Hark Rich of the Geology Department of the University of North Dakota for their suggestions and review of the report. The writer expresses his appreclation to the v.s. Goologleal survey, Ground water tranch, Indlanapolis, Indiana, and the vater Resources Division of the Indiana Departant of Conservation for their cooperation in obtaining openfile data and published reports ased in the thesis. Acknowledgments are wade to wembers of the ofrice stafs of the Ground Water Branch, Indianapolis, Indiana, especially Clauce M. Roberts, District Geologist and J. S. Wosenshein, project chief, for their review, suggestions, and contributions to the thesis. Special thanks are due many well arillers for their cooperation in supplying well data. 
Appreciation is given to Rlaira Vig for her assistance in br preparing the plates and typing the report. 


\section{CEOGRAMHY}

Phys Lography and Topography

Lake County is near the geographic center of the Eastern Lake Section of the Central Lowland province (Pernesan, 1938). This province is part of the sreat Interior Plains, a major physiographic division of the United States that extends fros the Applachian Sountains westward to the Rocky Mountains.

Malote's (1922) physiographic classification of Indiana places Lake County in the "Northern Moruine and Lake Negton". This region is subdivided into $f$ ive units and ineludes all the slaciated area north of the Vabash River. Three of Malott"s subdivisions, the Calumet lacustrine plain, the Valparaiso exoraine, and the fankalree lecustrine plain occupy parts of Lake County.

Lake sedinents are not extensive in the county and wore deposited in a sall area noar Hobart. The Kankakee plain 1. composed aninly of glactofluvial sand and gravel. Therefore, Malott's Caluset lacustrine plain and the Kankakee lacustrine plain are called, In this paper, the Calumet lake plain and the Kankakee glaciofluvial plain, respectively.

The northern rogion, or Caluset lake plain which was covered by flacial lake chicago, extends about 14 iles south of Lalke stehigan on the west side of the county and narrows to nine alles at the porter County Iine. The land surface of the Iake plain slopes toward Lake Hichigan and ranges in elevation fron about 580 feet, the approxiate sean lake 
Yevel of Lake Michigan to about 640 feet above mean sea level hit the edge of the Valparaiso woraine. The gentiy rolling surface has ancient beach lines that show the phases of former glacial Lake Chicago. The maximum locul relief of the Calumet lake plain is in the northeastern part of the county near uiler's Beach where sand dunes, the result of wind action, rise more than 150 feet above Lake Michigan.

The central region or Valparaiso woraine covers nearly half of the county. This woraine, which trends east-west across the county, is about 14 wiles wide on the east and about 18 wiles wide near the Illinois boundary. The moraine has a more rugged surface than either the Calueet or Kankakee plains, although a large portion of the moraine is relatively flat to undulating.

The highest elevation in the county is within the woraine region northeast of Palmer near the porter County line. (See plate 1,) The woraine here has an elevation of about 790 feet above mean sea level, which is about 210 feet above the aean level of Lake Michigan.

The southern region or trankakee glacioflavial plain occuptes atrip approxinately five alles wide between the Valparaiso moraine and the Kankakee River. The slope of the land surface is southward off the southern edge of the aboraine and toward the Kankakee River. Except for a few sand ridges the southern region has little relief and elevations range fron about 630 to 650 feet above mean sea level. 


\section{Drainage}

The crest of the Vilparaiso moraine is the divide which separates the natural Arainage of the streass that flow toward the North Mtlantic from those that flow toward the Gulf of Mexico. The divide across the eounty is developed entirely on glacial deposits of late pleistocene age.

The land surface north of the alvide is drained by the Litle Calumet and the Grand Calumet livers. Originaliy these two streass were called the Calumet River, as there was no differentiation into two rivers until a channel was Aug between the lake shore at south Chicago to Calumet Lake. This channel became the outlet for the two streass, as the flow of the lower portion of the forwer Calumet River (Grand Calumet River) was reversed. This reversal was possible only because of the very low gradient of the strean. The Little Calumet River is the apper portion of the original Calumet River.

Construetion of the Sag Canal across the Continental Divide diverted the drainage of the Little Calumet River frow the st. Lawrence to the Masissippi drainage basin. Burns Diteh near the boundary ine between Lake and Porter Counties was aug to allow the excess flow of the upper reaches of the Little Calumet Miver to alscharge airecty into Lake Michigan. This alkes the littio Calumet liver unique as its water can be diverted into either of two major drainage basins. 
The two aaln tributarios of the Little Caluat Wiver are Turkey Creek and Deep niver. The bendwaters of these two streans are loss than half a wle apart, being separated by a monainal ridge two alles east of st. Jolun. Turliey Creek flows down the north slope of the soratne onto the Calaset lake plain and then turss eastward and flows between the sand ridges, located on the north, and the Valparalso moralae on the south uncil it joins Deep Wiver near fobart. The valn tributary of the Lit le Calumet River is Deep Qiver which collects the drainage of 1 ts branches and dreaged aitehes from st. John to Palmer. Meep River has wany right angle bends in its course; a pattern that is controlied by the irregular deposits of glacial Arift. The stream flowing down the natural gradient of the land surface, is forced to change direction and flow around these Arift deposits. One of the wore conspicuous right angle bends is at the porter County Iine near Deep Miver. Here the otrearia turas abruptiy north, having cut a valley since postsiacial the 30 to 40 feet deep through a sag in the moralnal $r$ idge. The Rankakee wiver recelves no direct drainage off the south slope of the alvide wthin the boundary of lake County, as levees have been constructed aloug the river to prevent flooding. Singleton bitch collects water from the streams rlowing off the woraine and also draing water fron the reclaimed swamp land. This ditch connects with lagle Creek near Range Line and extends southwest across the southern 
part of Lake County into IIIInois where it expties into the b. Kankakee River above Momence.

Spring tun, Cedar, Eagle, and weat Creeks arain the south slope of the moraine and oceupy valleys that were once Arainagoways for welt water pouring off the front of an lee sheet. The valleys are relatively short and straight and the aclt water from the ice front traveled only a short aistance before exptying into a lake (Leverett, 1915) in the Kankakee arainage basin.

\section{Climate}

The climate of Lake county, classifled according to Thornthwaite $(1940$, p. 67), is humid, first sesotherwal, no season of water deficiency, and a teaperature-efficiency regle normal to second sesotheral.

Average annual air temperature is about $51^{\circ} \mathrm{P}$. The growing season is asually 170 days in the sorthern part of the county and 160 days in the southern part (Visher, 1944, p. 122).

Average annual precipltation is 33 inches. Although the precipitation is falrly well aistributed throaghout the year, the winter wonths are sosewhat drier. Table I gives the average wonthly precipitation and tesperature at the weather station in Gary, Indiana. 
Table 1.-Average monthly precipitation and temperature at Cary, Indiana,

$$
\text { 1936-1959 ( } 1 / \text { ). }
$$

\begin{tabular}{|c|c|c|}
\hline Wonth & $\begin{array}{c}\text { Average } \\
\text { procipitation } \\
\text { (inches) }\end{array}$ & $\begin{array}{c}\text { Average } \\
\text { temperature } \\
\left({ }^{\circ}\right)\end{array}$ \\
\hline$J$ anuary-m- & 1.90 & 28.0 \\
\hline February-- & 1.40 & 28.0 \\
\hline 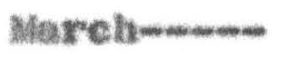 & 2.60 & 37.0 \\
\hline Apr11-m-m & 3.00 & 48.0 \\
\hline May & 3.50 & 59.0 \\
\hline June-m-- & 3.60 & 69.0 \\
\hline 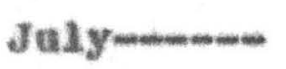 & 2.80 & 75.0 \\
\hline Augrast-m-- & 3.40 & 73.0 \\
\hline Septenbor- & 3.50 & 67.0 \\
\hline october m-n- & 3.10 & 55.0 \\
\hline Novenber-- & 2.60 & 41.0 \\
\hline Decenduer-m & 1.90 & 29.0 \\
\hline Annuar 1 - - - & 33.30 & 50.5 \\
\hline
\end{tabular}

$y$ Data frow U.S. Weather Hareau. 
Econony Related to Surface Peatures

The econoay of the eounty is related to its strategic location and the general Platness of the area. Bast-west land traffie is compelled by Lake Mchigan to converge al toward the Calumet lake plain. Also, the Creat Lakes watertransportation syste: focuses on this area. Many large industries have located in dammon, East Chicago, whiting, and Gary.

Ninety-one percent of the population in Lalke County is concentrated in this industrial area on the Caluaet lake plain. Table 2 shows the areal asstribution of the popalation with respect to the three physiographic divisions of the county.

The relatively flat top of the Valparalso tavaine and the plane-11ke surface of the Kankakee region are saitable for faraing. The agriculture products from these two rogions have a roady market in the Calumet and Chicago areas. The wajor erop and 1ivestock production are shown in tables 3 and 4.

water is an important natural resource of great economic value to Lake County. Lake Michigan is the chief source of water supply for the sunicipalities and industries of the Calumet lake plain and ground water is the source of water supply for the Valparaiso and Wankakee regions, Other. natural resources of econonic value inelude: (1) sand, used for road construction and many other purposes; (2) clay, 
used in the manufacturing of clay products; and (5) peat, b. used as ferthizer. 
Table 2.-population and 1 ts distribution with respect to the physiographic Aivisions of Lake County, Indiana 1 .

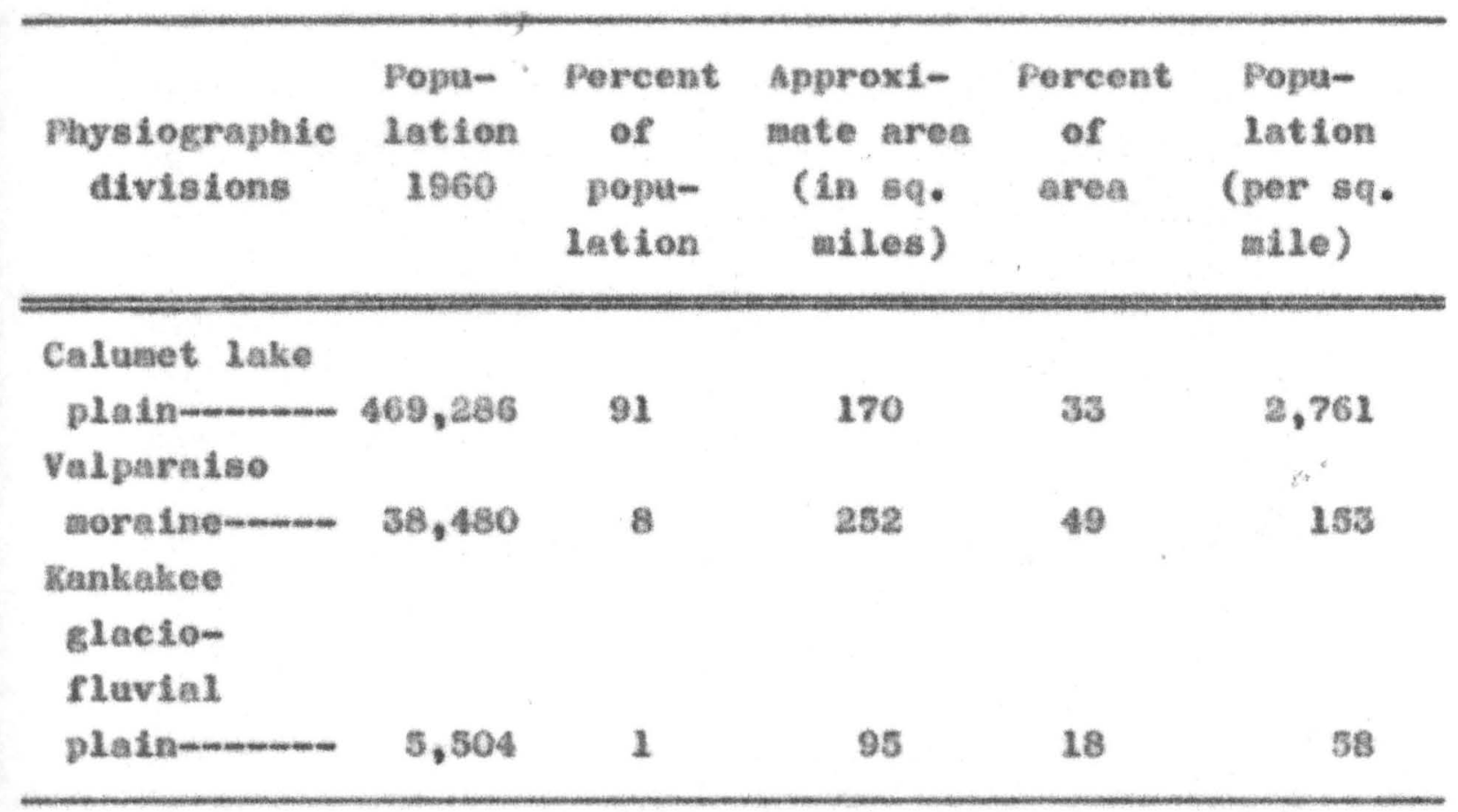

L/ U.S. Census of population, v.S. Department of Commeree, Bureas of Consus, Indiana, 1960. 
Table 3.-Crop production in Lake County, Indiana, 1959 and $19541 /$.

\begin{tabular}{|c|c|c|c|c|}
\hline Products & $\begin{array}{c}\text { Acreage } \\
1959\end{array}$ & $\begin{array}{c}\text { Eushels } \\
\text { harvested }\end{array}$ & $\begin{array}{c}\text { Acreage } \\
1954\end{array}$ & $\begin{array}{c}\text { Bushels } \\
\text { harvested }\end{array}$ \\
\hline Corn-m-- & $68 ; 548$ & $4,391,760$ & 61,395 & $3,536,141$ \\
\hline Wheat-m-m-m- & 11,411 & 357,311 & 11,572 & 572,160 \\
\hline Oate-m-m- & 12,343 & 530,596 & 21,163 & 750,314 \\
\hline Soybeans-n- & 33,958 & 276,516 & 25,295 & 672,211 \\
\hline Potatoes- & 110 & 25,789 & 89 & 21,356 \\
\hline Vegetables- & 2,630 & - & 2,900 & - \\
\hline
\end{tabular}

$1 /$ Data from $U .8$. Census of Agriculture, 1959.

Table 4.--Livestock production in

Lake County, Indiana, 1959 and $19541 /$

\begin{tabular}{|c|c|c|}
\hline Products & $\begin{array}{c}\text { No. raised } \\
1959\end{array}$ & $\begin{array}{l}\text { No. raised } \\
\text { I054 }\end{array}$ \\
\hline Cattle-m & 20,387 & 24,532 \\
\hline Hogs & 22,499 & 20,669 \\
\hline Sheep-m-m- & 3,315 & 2,986 \\
\hline Chiekens- & 104,370 & 151,158 \\
\hline Tarkeys-- & 22,225 & 28,451 \\
\hline
\end{tabular}

1 Data from U.S. Census of Agrieulture, 1959. 


\section{GeOLOCY}

Geologie setting

Lake County is in the central stable region of the United States (Eardley, 1951, D, 26). This area bas a basement coaplex of crystalline rocks of Precabbrian age that is overlain by sedimentary rocks. The depth of precanbrian rocks in Lake County is estinated to be about 3,300 feet below sea level (Renderson and zietz, 1958, p. 28). Sedimentary rocks of Devonian, silurian, Ordovician, and Canbrian ages were deposited in Lake County during the Paleozole Era. The Mt. Simon Bandstone of Canbrian age is the oldest formation encountered by drilling. A well was drilled at Crown point to a depth of 3,100 reet below land surface (Blatehley, 1597, D. 44). The data from the well log is interpreted by the writer to have penetrated into the Ht. Sinon sabistone, based on data presented by (Cutstadt (1958, p. 19-25).

Apparently during the Cambrian and ordovician Periods no earth movement of significance eccurred in the central atable region. The Milinols and Michigan basins were originally a continuous structure (Bardiey, 1952, p. 29) which probabiy had its origin in the ordovieian but the strueture was not strongly expressed. An uplift area originating in the Silurian (Freeman, 1951) divided the structure into two parts. The uplift is known as the kankake arch (Bkblaw, 1938, p. 1426) and is apparently related to the northwest 
prong of the cineinnati dome, and to the southeastwardtrending arw of the Wisconsin areh. The Kankakee arch that underlies the southern part of Lake Coanty acequired its structural relief by greater subsidence of the basins on its sides rather than by actual uplift (Rardley, 1951, p. 36 ).

The belrock surface beneath the glacial deposits consists miniy of dolonite or delomitic limestone of Silurian age. The youngest Naleozolc rocks in the county are the scattered erosional rewnants of Devonitan shale. According to well records and the cross sections of platess 5,6 , and 7 the Devonian shale lies above the sllarian rocks in the center of the county in the vicinity of crown point and in the extreme southern part near Shelby (fig. 2). These deposits indicate that sediments of Devonian and probabiy sediments of post-Devonian age were deposited over the area. Erosion has reiaoved any gediments that way have been deposited between the Devonian and plefstocene time.

In late Cenozole time continental glaciers advanced fros Canada, overriding the eroded bedrock gurface and leaving widespread glaeial deposits. The sce sheets apread over the northern part of the United states and covered all but the southern part of Indiana ( $\mathrm{fig} .1)$.

Four Independent atages of glaciation aro recognized in North America. They are, frow oldest to youngest, Nebraskan, Nansan, IIIInolan, and isconsinan. The glacial stages were separated by Interglacial atages, Auring which 

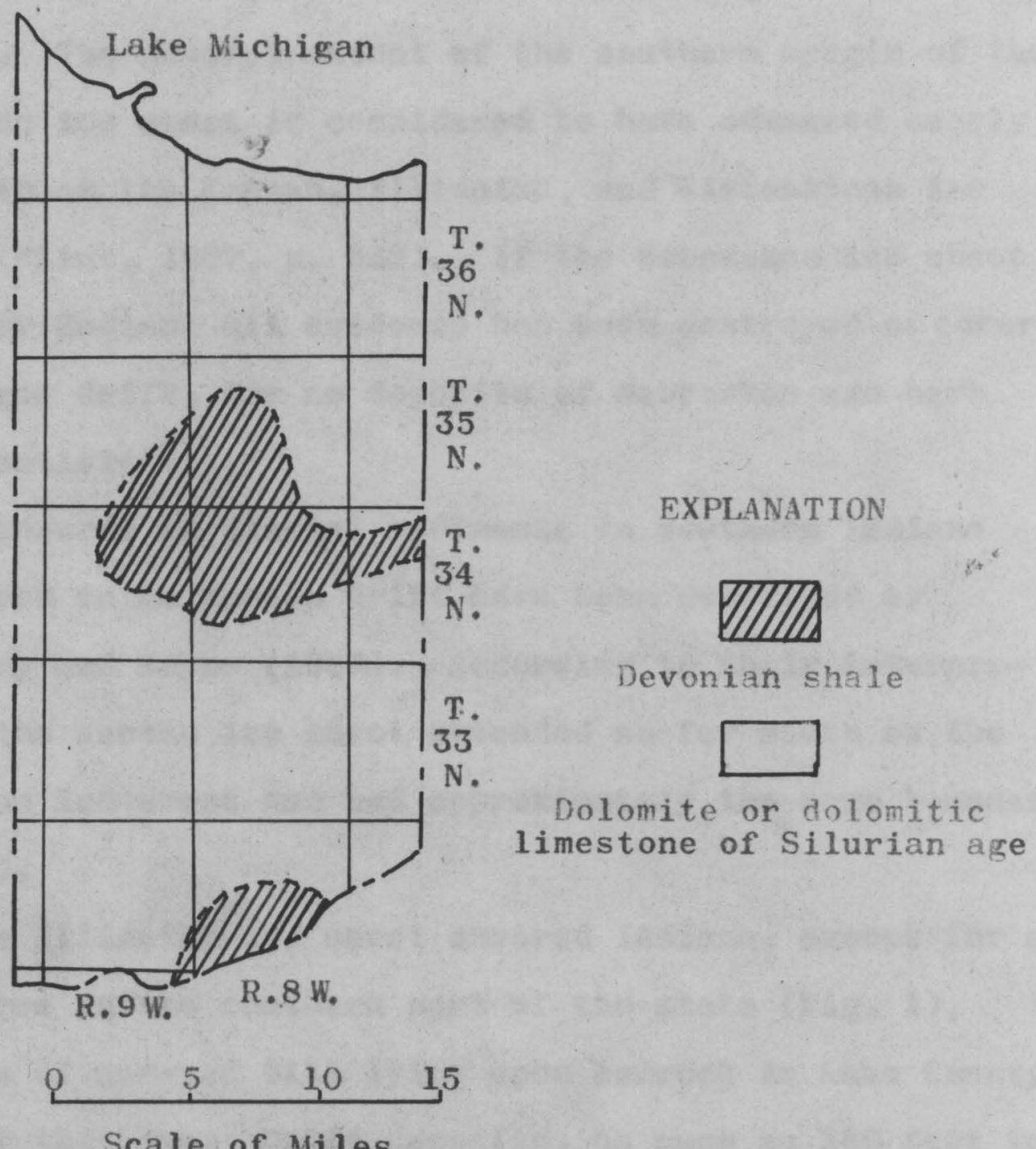

Scale of Miles

Figure 2.--Diagrammatic bedrock surface map of Lake County, Indiana. 
the clinate was probably as temperate as it is at present. There is no evidence of the Nebraskan glaciation in Indina. The general extent of the southern axargin of the Nebraskan ice sheot is considered to have advanced nearly as far south as the Kansan, M11inolan, and wsconsinan ice sheets (F1int, 1957, p. 338). If the Nebrakan lee sheet did enter Indisna all evidence has been destroyed or covered by younger arift, for no deposits of Nebraskan age have been Ldentified.

Lxposures of eflacial sedisents in southern Indiana considered to be Kansan arift have been described by Thornbury and wayne (1957). According to their interpretation the Kansan ice sheet extended as far south as the Illinolan ice shoet and had approximately the sase boundary (fig* 1$)$.

The IIIInolan lee aheot covered Indiana, except for a small area in the southern part of the state (fig. I). Deposits of undated t111 Iy Ing apon bedrock in Lake County maybe of that age. Drift deposits, as wen as 150 foet in thickness, separates this older till fros the younger Valparaiso t111 of Wisconginan age. This older, gray-blue, elayey t111 which overlies the bedrock is exposed in two pits north of Highland. No evidence of decoaposed till was found to indicate a prolonged interval of weathering. Evidentiy, the upper veathered surface wa resoved by latter gleciation or eroded by the water (wave action) of glacial. 
Lake Chicago.

Sand and gravel underlying the Valparaiso moralne extends southward away fros the woraine and crops out on the Kankakee glaciofluvial plain. This outwash probably was laid down during the retreat of the lce shoet that deposited the clayey till upen the bedrock. Therefore, the sand and gravel is probably Illinolan (?) in age.

A revised classification of the forwer visconsin glaciation is used in this thesis ( $f$ ig. 3). The revised tiwe-stratigraphic classification of the wisconsinan Stage of the Lake Michigan lobe as used by the 111 inois state Geological survey is based on new data frow raliocarbon dates (Frye and willman, 1960, p. 2).

The Wconsinan glaciation was the fourth and last major lee sheet advance into the central part of the United states. The history of the substages of this ice sheet is wore readiy reconstructed because of the excellent preservation of their deposits.

The Valparaiso meraine, a broad upland, encireling the south ond of Lake Michigan trends east-vest across the central part of Lake County, This moraine has been traced northwostward into Mlinois and northeastward into Miehigan. The glacier which deposited the Valparalso moralne retreated an anknown distance and then the ice readvanced, encroaching apon the Valparaiso moraine. The end woralne left by the readvance of the ice is herein called the Tinley moralne. 


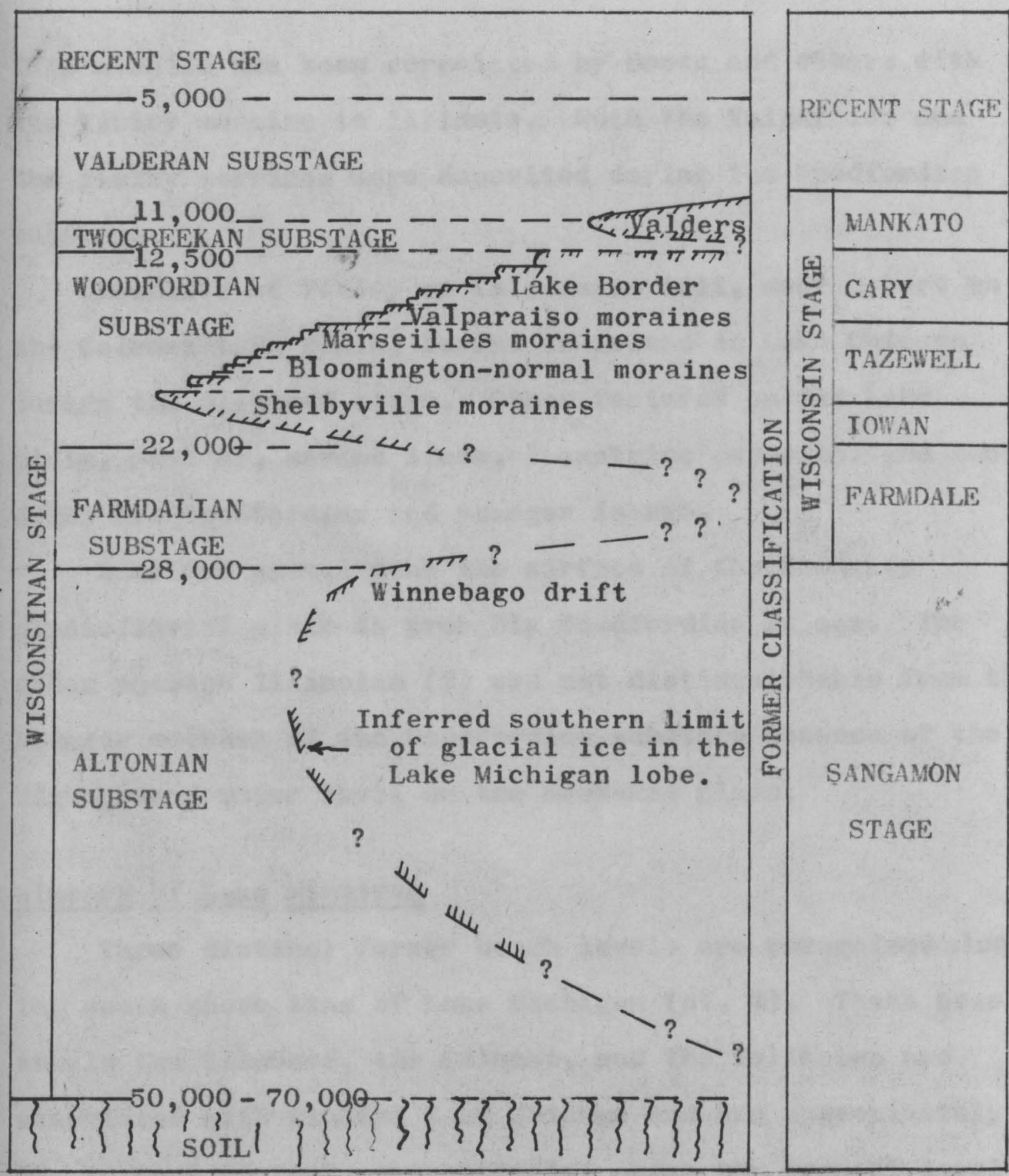

Figure 3.--Time-stratigraphic subdivision of the Wisconsinan Stage in the Lake Michigan glacial lobe. Only part of the named moraines in Illinois are shown, and named moraines are morphostratigraphic units. The inferred limit of glacial ice through time is shown diagrammatically on a vertical scale in radiocarbon years. After Frye and Willman (1960, fig. 1). 
This moraine has been correlated by Bretz and others with the rinley woraine in IIIInois. Doth the Valparaiso and the Tinley moraines were deposited during the woodrordian substage.

Remants of Tinley or Valparaise til1, near llobart on the Calumet lake plain, forwed an island in Lake Chieago during the Glenwood stage. Other features on the Lake plain, such as, strand lines, lacustrine deposits, and sand tunes are 籍oodfordian and younger in age.

Sand and gravel near the surface of the Kankakee glaciorluvial plain is probably vooderaian in age. The older outwash IMinoian ( $?$ ) was not aistinguishable froe the younger outwash of the woodfordian substage because of the high ground-water level on the Nankakee plain.

\section{History of Lake Michigan}

Three alstinct former beach levels are recognised along the south shore line of Lake Michigan (pl. 2). These beach levels the Glenwood, the Calumet, and the Tolleston are associated with glacial Lake Chicago and are approximately 55,40 , and 20 feet, respectively, above the present level of Lake Miehigan.

The early geologists stated that lake Wichigan attained its present level by a series of steplike lowerings. Lowering to the Tolleston level was generally considered to have been caused by lake water overflowing the morainic 
dam, a low seguent in the Valparaiso woraine, in the vicinIty of the already-existing Sag and Desplalnes Valleys. Mccording to this theory, Arainage toward the Mississippl River ceased when the level of the former lake reached the Tolleston beach level as bedrock in the chicago outlet prevented further down-cutting. The retreating ice uncovered a new outlet to the north with arainage into the st. Lawrence basin and lowering contiuued to the present level of Lake Michigan.

Later investigations have shown in the aiscovery of buried peat beds and a buried soll profile (Bretz, 1951; Zumberge and Potzer, 1936), that Low-water phases occurred during the Mistory of glacial Lake Chicago. This new evidence has required sose revision of the former interpretation of the history of the Groat Lakes.

As the ice receded northward into the Lake Midhigan basin, during the woodfordian substage, glacial Lake Chicago was formed between the lce front to the north and the Valparaiso woraine to the south. The lake water Alscharged across the morainie dam in the vieinity of the Sag and Desplaines Valleys to enter the Mississippi Arainage. The Glemwood and Calumet phases correspond to stilistands of glacial Lake Chicago produced by resistant boulder pavements in the outlet channels. Bedrock rather than boulder pavement prevented further down-eutting during the Tolleston phase (Bretz, 19s5, p. 109). 
alaclal advanees during the Glenvood and Calunet phases blocked outlets to the east and increased the alscharge from glacial laltes in Ontario, southeastern Nichigan, and western Ohio into glacial Lake Chicago. The greatiy Increased volume of water caused the reaval of the boulder pavenents, deepened the discharge outlets and lowered the level of glacial Lake chicago. The two eplsodes of channel deepening lowered the lake about 20 reet each $t i n e$. Dedrock In the chlcago outlet prevented farther down-cutsing and establisked the lovel for the rolleston stage. Retreat of the lce to the north uncoverod lower outlets which resulted In further lowering of glacial Lake Chicago.

At least twice during the history of glactal Lake Chlcago the ice front recoded far enough to the north to open the Mobawk and Hudson outhets to the east. The discharge through these newer outlets lowered the lake lovel below discharge levels of the southwestern outlet of the Sag and Desplaines Valleys (Aretz, 1955, D, 114). An extremely low water level in the Lake Mehigan bas $1 n$, known as the Lake Chippewa phase, estituted to be 350 feet belov the prosent Lake Michigna Level, resalted (Lough, 1958, p. 238).

Wth the Alsappoarance of the Wisconsin ice sheet fron the Great Lakes region, rebound through crustal upwarping raised the clevation of lake Michigan"s outlet to the st. Lawrence Aratnageway (Hough, 1953, p. 135). The prosent 


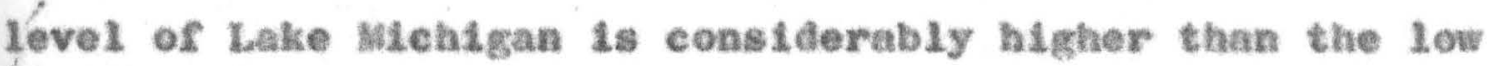
level of the Lake Chippewa stage because of this crustal. upwarping.

\section{Dedrock Topography}

The general conflguration of the bedrock surface anderlying Latce County is shown in plate 5. The contours on the bedrock surface were complied from wore than 250 records of wells penotrating bedrock and from 31 seisale deterainations (See plate 4). The depth to bedrock can be estimated by gubtracting the value of the bedrock surface contour (fil. 3) from the value of the land-surface contour (pl. 1).

The general slope of the bedrock surface is toward the Lake Michigan basin. In the southern part of the county the bedrock surface is nearly flat and has a sradual slope to the east and southeast $(p 1,3)$. The highest point on the bedreck surface is more than 625 feet above wean sea level in the southwestern part of the county and is the only place where the bedroek aurface rises above the aean level of Lake alchigan (s\$o reet). The bedrock topography of the western mart of the county is wore rusged than in the eastern part and rises in elevation frob about 450 feet near Lake Michigan to about 625 feet near the Kankakee R1ver.

A preglacial drainage divide that separated the anelent Mississippi River froa the St. Lawrence Arainageway to tho east Is located In IIILois fow miles west of Lake Coanty 
(Horberg, 1980, p. 44), The aivide trends north-south and probably erosses the southwestern corner of Lake County. Pive preglacial strean valleys ( $\mathrm{rig}$. 4) entered the county frow IIInois. Their source was near the erest of the Aivide. All these streas valleys are at elevations loss than 450 feet above wean sea level in the vieinity of the present Lake Michigan.

The bedrock and shows a valley entering Lake couvty in the SWF sec, 36, T. $37 \mathrm{~N}$, , N. $10 \mathrm{~W}$. This valley is a continuation of the barled lladey Valley in Illinols (Norberg, 1950, D. 44; Suter and others, 1959, p. 21). In progliélal time the stream in Madley Valley flowed toward the Lake Michigan basin. Horberg (1950, p. 44) reported that prior to Illinolan time the flow was reversed and also suggested the existence of an ancestral Lake Chicago. The alscharge fros this lake apparently breached the bedroek divide and cut a deep trench aro then 50 feet below the Chleago outlet.

Near Dyer, Indiana a buried valley trends northeast and probably joins ladiey Valley north of the present shore of lake Michigan. The stroams of these two valleys had lew gradients and flowed on rocks of silurian age.

The reanining three bedrock valleys eonverge near Cook, Indiana to fors the longest preglacial valley in the county. The valley has a general north to northeast trend and enters the Lake Michigan basin about two ailes west of Porter County. This valley may conneet with the preglacial valley 


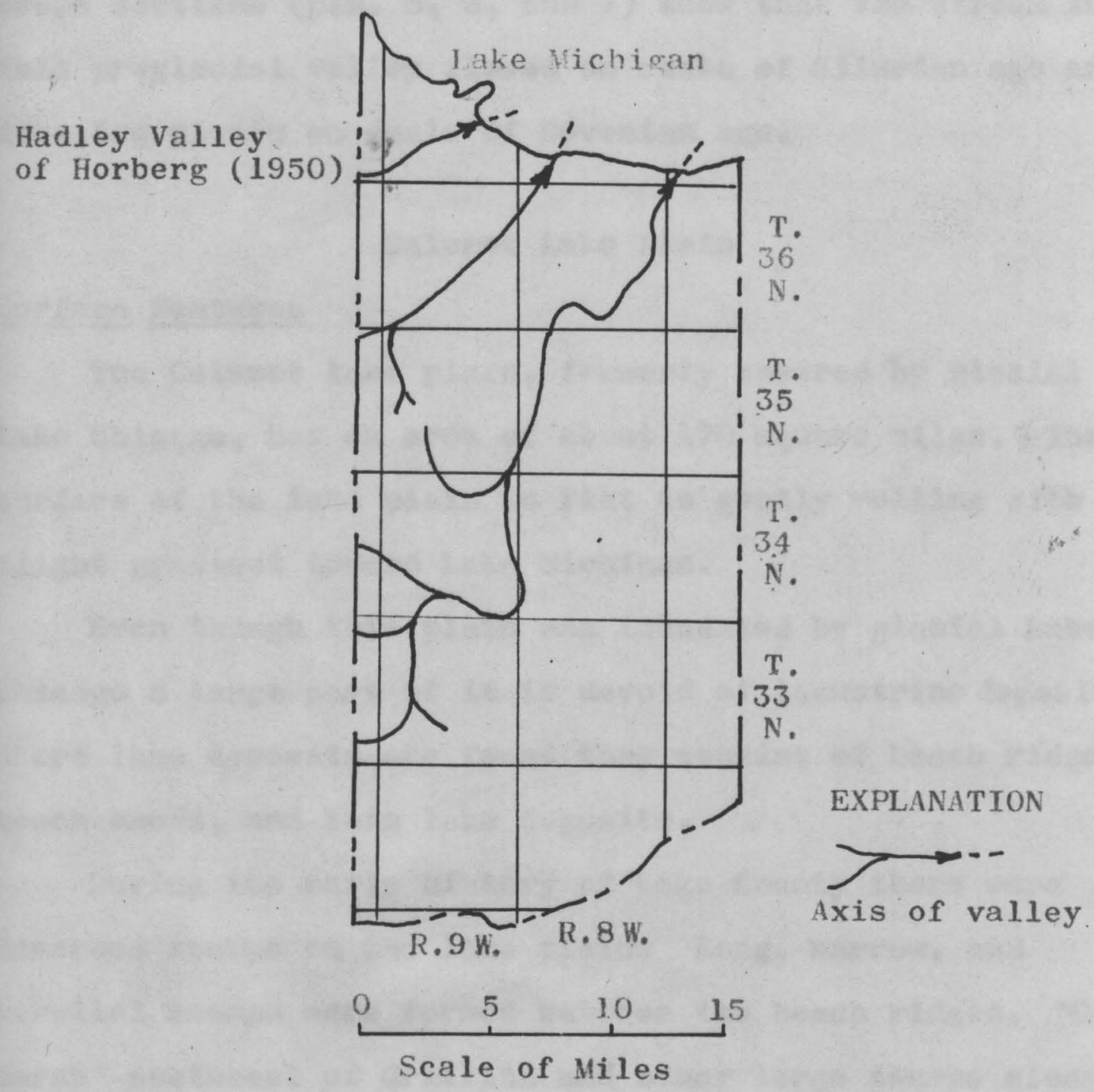

Figure 4.--Diagrammatic map of Lake County, Indiana, showing bedrock valleys. 
in porter county described by wayne (1956, p. 34$)$. The cross sections (pls, 5, 6, and 7) show that the strean in this preglacial valley flowed on rocks of stlurian age and in a rev places on shale or Devonian age.

\section{Calunet Lake Plain}

Surface. Eeatures

The calumet lake plain, formerly covered by glacial Lake Chicage, has an area of about 170 square wlies. The surface of the lake plain is flat to gently rolling with a silght gradient toward Lake Michigan.

Even though this plair was inundated by glacial luatre Chicago a large part of it 1 devold of lacustrine deposite. Where lake deposits are found they consist of beach ridges. beach sands, and thin lake deposits.

During the early history of Lake County there wore numerous swalaps on the lake plain. Long, narrow, and parallel swanps were formed between the beach ridges. "Cady Marsh" southeast of Griffith and other large awangs along the Little Calumet fiver aro shown on the solls anp of Lake County (Bushnel1 and Barrell, 1921). Many of these ewangs have been drained or rilled.

Nrior to aan"s occupancy the south shore Iine of Latre Hehigan was a swooth curve. Reclathation of marshland for Industrial expansion and dumping of Industrial waste products and other f11. material behind bulkheads extending out into 
Lake Michigan has changed the shore line in many places (p1. 2). At whiting, on the leke front, a bluff having the appearance of rock is conposed of waste slag frow the steel a11s.

Beaches of Lake. Chicage.--The wost conspicuous deposits left by glacial Lake chicage are the bench ridges that stretch for wles across the lake plain. Sand besch deposits were built on land at the waters edge by wave action, or as bars sowewhat offehore at the line of breakers. The relative elevation of some of the bench ridges is increased by dunes of wind-blown sand.

The bighest beach of glacial take chicage is called Glenwood beach, the name given to a sillar feature at Clenwood, Illinois (Leverett, 1915, p. 350). This beach passes through Dyer and continues eastward across the county (p1. 2). Clenwood beach is alscernible between Dyer and Schererville, but east of Bchererville the beach is indistinct because of the aany embayuents along the valparaiso moralne.

Remnants of the Tinley or the Valparaiso till near Hobart formed an island in Lake Chicago during the clenwood stage (pl, 2). From this island a spit formed that extended to Griffith. Deposition of material transported by longshore currents was built up into sand ridges by wave action to form the spit. The north side of the spit is a siaple curve, but the south side has three successive "fingers", 
rídges of sand projecting southward. Storn waves tended to swing the end of the spit to the south but the addition of debris shoaled the water and the growing spit fingers were abandened and new ones were bailt. Cravel pits in sec. 36,

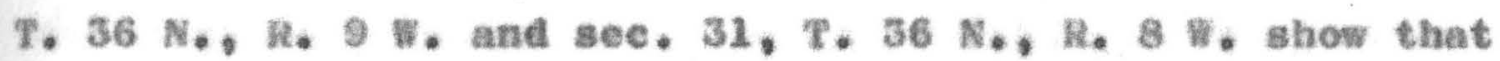
the spit consists of stratified sand with pebbles dispersed throughout.

Calumet beach parallels the little Calumet liver in the county from lunster eastward to porter County (pl. 2). This shore line is well defined and capping sand cunes have ande the beach ridge wore prominent. Mighways $U .3 .6$ and U.S. 41 (Ridge road) follows the crost of the Calumet beach. According to Hough $(1958$, p. 182), the lake stage produclng this ridge had only a relatively brief existence.

The lowest of the three prominent beaches of glaclal Lake Chicago is named Tolleston beach. The name is taken frow an early settlenent which lis now part of cary (Leverett. 1915, D. 356). The beach enters the state from the west on the south side of Hanmond and trende castward about widway between the Little Calumet and Grand Calumet Rivers (pl. 2). Hest of Gary the lake plain is characteriaed by long, narrow, parallel, sandy beaches indLoting successive lowering of the lake. Between the rolleston beach ridge and Lake Michigan, 70 of these long, parallel, sand ridges have been counted on aerial photographs (Blobor and Salth, 1952, p. 10). The Tolleston beach ridge and the sand ridges to 
the north are betng destroyed by Industrial and arban land br dove Lopwents.

Sand was derived from weathered glacial drift, sandstove, and other quartz-bearing rocks. The bluffs (glacial drift) was undernined and the material was aorted by wave action along both the eastern and western shores of Lake Michigan. Sand derived from the glacial drift, and sand brought in by streans and rivers was traksported to the head of Lake Mchigan by Longshore currents from both sides of the lake.

Erosion of the blufrs and deposition of sand along the lake shore has continued for thousands of years and is still. actively solns on. Leverett (1899, p. 282) stated that a strip 150 reet in width between waukegan and fvanston, ILInols was underwined and carried into the lake during the thirty years frow 1860 to 1890.

The beach sendas are we11 sorted and over 00 percent of the grains are elassified as adiun to fine sand (pettifolun, 1949, D. 233; Deber and Satth, 1952, p. 17). The sands Increase In coaraeness westward Into IIIInols and eastward toward Mehigan. The change in grain sise is protsably related to the distance from the source and to the longshore currents which carry the sand southerard to Lake County at the head of the lake.

Cressey (1988, D. 31) steted that grante grains const1tate are than 90 percent of the beach and dane sands. 
other lightweight winerals are prineipaliy reldspars. Carל. bonate minerals anount to little wore than a trace. The heavier minerals (specific gravity wore than 2.25) are auphibele, pyroxene, Illwenite, wagnetite, eplatete and garnet (Pettijolun, I931; p. 438). Nefuse, especially slag, is being added to the beach sands fros steel and other industries located along the shore of Lake Michigan. Danes.--Another striking feature of the Caluset lake plain is the sand dunes in the northeast corner of the county. A dune belt extends from Gary in Lake County to Michigan city in LaPorte county. The highest dunes in the county are southeast of biller and are about 150 reet above the mean level of Lake Michigan. West of Gary asaller dunes were forwed and in places wind-blown sands have capped some of the beach ridges.

The dunes were forwed by winds, blowing aeross areas of sand that had been deposited along the shore. Since the doninant winds are from the southwest and northwest, the dunes are best developed on the southeastern shore of lake Michigan, Vegetation has stablized sost of the dunes. The composition and grain size of the dune sand does not vary greatly from the beach sand, frow which it is derived. The beavy ineral content of the dunes is sightiy less than that of the beach sand. The Iighter weight amphibole, pyroxene, and epldote predosinate over such anerals as ilimenite, tagnetite and garnet (Bieber and 
gatth, 1952, p. 19).

The sand dunes began as a serles of fore-tune ridges which probaliy ald not migrate far inland after their formation. Cressey $(1928, p, 48)$ reported that the complex of dunes is not related to the present shore of Lake Michigan, but was forted by widening of the beach and the formation of successive fore-dune ridges. The widening of the beach was caused by deposition of sand carried by longshore currents, shouling of the water, and extending the shoreIne to the north.

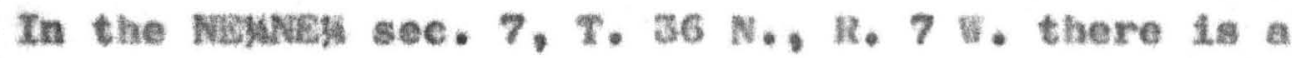
sand dune with an exposed face of wore than 50 feet. A nonconforwable contact clearly shows that recent wind-blown sand is deposited over an older dune sand. The slope of eolian cross-bedding varies in direction and dip. The angle of alp on the windward slde is usually lower than on the leeward side, where maxisua dips as weh as 35 degress occur. The bedding is indistinet in a newiy cat face, but very distinct in the older wind-eroded face. The fact that the individual layers vary in graia size accounts for separation inte beds. The coarser sand is white to light buff. Usually the beds containing the amaller grains are a darker buff and the sand Is slightly Indurated by cementation. The cenenting substances are calcium carbonate, iron oxide and contained clay particles. 
Súbsurface Devostts

The unconsolfdated deposits of the Calumet lake plain consist of and and gravel that ranges in thickness fros a thin veneer at the north edge of the Valparaiso moralne to were than 30 feet near Lake Michigan. This sand and gravel. overlies a sray-blue clayey $t 111$ that averages ano than 50 feot in thickness.

In the sanww sec. $31, T_{*}, 36 \mathrm{~N},, \mathrm{R}_{0} 9 \mathrm{~W}$, about 14 reet of till is exposed. In the lower 8 feet a gray-blue till contalns wany shale pebbles of Devonian age derived locally froa the blue-black shale of the Lake Michigan basin. The upper 6 feet consist of 5 reet of yellow, silty, clay till overlain by 1 foot of weathered, silty, elay soll. The yellow, silty, elay till is rinley or Valparaiso ground moralne overlying the gray-blue till of pre-liseonsinan age. There is no indication of a weathered zone separating the two tills.

North of Mighland on the Calumet lake plain in the NEy

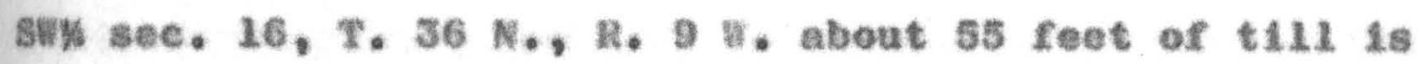
exposed. Till in this pit is considered by the writer to be prewisconsinan, Milnoian (?) in age. The till lies upon bedrock and extends southward beneath the Valparaiso woraine (pl, 5). The younger Valparaiso till of woodfordian age is separated from the older IIIInolan (?) t111, which lies on bedrock, by glacial drift which is wore than 150 feet thick in places. 
A silt about 3.6 feet thich separates the two till deposits, ladicating two lee advances in this exposure. The upper part of the silt is finely bedded or laminated and appears to be cross-bedded in places which would indicate moving water. Bedding is absent in the lower part of this silt. The silt contains no pebbles.

Two foet of weathered, burf, silty soll is at the top of the pit. Helow the soil aone is 30.6 feet of till. This t111 has a gray-biue color when wet, and becowes gray, hard and cospact when ary. The till contains pebbles and lots of shale fragaents. Beneath this till is the silt aone, 3.6 feet in thiekness. Below the silt is 20.4 feet of till. This till is similar to the till above the silt, except, that it contains rewer pebbles and shale fragraents. No cobbles or boulders were observed in the pit, although sove maybe covered by 15 feet of water at the base of the pit.

Near the Eittle Caluwet Miver northeast of fighland in the MBW sec. $22, \mathrm{~T}, 36 \mathrm{~N},, \mathrm{~K}, 9 \%$, about 15 reet of material Is exposed. Pelecypods and gastropods are found in the upper 2.8 feet of material. The writer considers the shells to be frow an early phase of the Caluaet Miver's history rather than frow that of glacial Lake Chicago. This opinion was confirmed by Dr. Willan $J$, Wayne of the Indiana Geological Survey, who described the shells as being too recent to be fron Lake Chicago and typical of shells round along rivers and wasas. A graymblue till lies belew the 
shell zone.

Near Hobart and in adjacent parts of Porter County there are deposits of lake clays (pl. 2). These clays were probebly laid down in a bay that originally was part of Lake Chicago during the Glenweod stage.

Lake deposits 12 reot thick are oxposed in the abandoned clay pit at the Hobart Briek Hlant, Swy sec. 29, $\mathrm{T}$. 36 N., R. 7 . The upper 8 feet of the deposit contains layers of lasinated, sity, waroon clay separated by thin partings of tan silt. Calcareous concretions are found in horisontal layers and in vertical cracks in this elay 4 to 8 feet below the surface. The layers of waroon clay below this depth are about 0.2 feet or 3.6 inches thick and are separated by thin partings of tan silt or very fine sand. The layers are varve-like and probably represent eylic deposition. These lake deposits are reported to be about so reet thick and are described by Blatchley (1897) and Cressey (1928).

\section{Valparaiso Moraine}

The sassive end woraine that rises abruptiy above the Calusuet lake plain on the north and the Kankakee glaciofluvial plain on the seuth receives its name fros Valparaiso in Porter County. The Valparaiso voraine, which rises about 210 feet above Lake Mehigan, was buit by deposition during the Woodfordian substage of the Isconsinan ice age 
and by accusulations from former lee sheots that previously b advanced and receded over the area. Contours on the lodrock surface $(\mathrm{pl}, 3)$ show that the topographic expression of the Valparaiso voraine if not related to the configuration of the bedrock surface.

\section{Surface Features}

Surface featares of the Valparaiso woraine in Lake Cousty can be divided inte two distinet groups, In the soutbern section the topography is generally wore rugged and typical of morainic areas, The most impressive features of this section of the woraine are the elongated depressions between worainal highs which probably acted as drainagoways (spillways) for glacial selt waters rlowing toward the Nankakee Hiver. Numerous tributary depressions, foraerly streans, now stand high and Ary above the wain spiliways.

Morainie features in the northern section are generally subdued. Inoll-and-kettle type topography, cossson in aorainie areas, is usually absent. A large part of the noraine in this section is rolatively flat to undulating. No evidence of sand and gravel deposits, such as, eskers, kames, or kame terraces were seen on the surface of the soraine in Lake County. East of the county, in Porter County, the moraine becones wore rugged and the thll contains aore sand, pebbles, cobbles and boulders. This dif- 
fórence in the composition of the till is very noticeable in the road euts and in the plowed rields. plles of cobbles and boulders are seen in the fields and along the rence Ines in Porter County, but seldos observed in Lake county. Stratified sand and sravel deposits were also observod in Porter County.

All the till observed in Lake County has a very high elay content and a paucity of pebbles, cobbles, and boulders. The best example of the lack of pebbles, cobbles, and boulders is at a pit north of Mighland where 55 feet of till is exposed. Pebbles are found throaghout the till but no cobbles or boulders were seen. There mabe cobbles and boulders at the base of the pit; covered by water.

Fragments of Igneous and vetamorphic rocks are conspicuous but less conaon than shale and Ifwestone. This is understandable since glaciers carry very little rock material far beyond the place whore it is pieked up. source of the igneous and netamorphic rock is far to the north in Canada. The rowte of the advancing lce was through the elongated trough of Lake Michigan. Much less sandstone was traversed by the ice sheet then shale or linestone, hence the relative saall quantities of sand in the til.

The relative flat to andulating surface of the northern section of the woralne is designated as an ablation woralne on the surface geologie wap (pl. 2). The till is thought to have accumulated chiefly by lodgment beneath the fee and 
partly by being let down frow the apper surface of the lce through the ablation process. Apparently, the aeterlal transported by the lee into Lake County carried an Inadequate awount of sand and gravel to be reworked into stratified depesits. Therefore, the surface of the moraine is not one of knoll and depressions, containisg stratified features of collapse aterial, comoon to ablation worathe. The drift, because of its high content of clay, readily yielded to solifluetion and the relief on the woraine was reduced or nearly eliminated to forw an undulating plain.

Thinning occurred as the glacial front retreated frow the southern part of the woraine. Shrinkage of the glacier, direct result of thinning, slowed the flow of lee to the glacial borders. The lee in the end zone, because of the topographic high of the woraine, becase separated from the main body of lee and stagnated. No deposits of linear reatures were observed to indicate readvance or pauses in the retreat of the ice.

Throughout the moraine are awamps which remain as ovidence of former shallow basins that were filled with water from the melting lce of the stagnant glacier. These shallow lake were filled or are being filled by aquatic plant decay and wineral wetter brought in by slope wash. A level area north and east of Crown Point was the largest of these shallow lakes. The water was drained and the area is now being farwed. 
Leverett (1899, D. 345 and 1915, p. 216) reported that the Valparaiso moraine in lake county conslsts of three ridges; and since then, all glacial geologic maps have shown three distinct ridges, extending through the county. Nowever, topographic wape of Lake County show on Iy two ridges. The highest or saln ridge north of cedar Lake has an elovation between 750 and 780 reet above wean sea level. The Continental Divide follows along this ridge, which trends eastwest froa cook to the porter county line (pl. 2). Streams flowing toward the Kankake River from the alachal front, breached this ridge in wany places. Vnolls enclosed by the 750 root contours (pl. 1) are rennants of the ridge. The second ridge 1 s an end moraine that has been correlated with the Tinley soraine in ILinois (Brets, 19s9, p. 50). This east-west trending ridge enclosed by the 700 foot contour is north of st. John and varies in widh from balf a vile to a wles (pl. 2). The till of the riniey moralne is a buff to yellow, sily, clay till with sone embedded pebbles and cobbles. There is no apparent distinction between the Tinley till north of st. John and the Valparaiso till cropping out along 0.5 . Wighway 41 at the south edge of the Valparaise moraine. Protz (1955, p. 81) stated, To the eye and hand, the Valparalde till $1 \mathrm{~s}$ Indistinguishable frow the Tinley".

Horainic Lakes.--llost of the closed depressions that held moralnic lakes bave been destroyed or are swasps in 
the final process of destruction, of the few worainic lakes in the county the largest is Cedar Lake which is wore than two miles long and about three-quarters of a wle wide.

Cedar Lake was probably formed by welting of a large mass of stagnant ice. Ridges of glacial Arift enelose the lake on three sides and to the north rise 60 reet above lake level. The water once overflowed toward the Kankakee River through an outlet in the southern rim of the Make. Today, a das at the south ond of the lake regulates the lake level and is the outlet to Cedar creek. Cedar Luke has a snall drainage area that is fed by runoff from local precipitation, by effluent flow of ground water to the lake, and by springe. The southern end of the lake is alowly being filled by aguatic vegetation and slope wash.

Pancher Lake at the county fairgrounds southwest of Crown Point is on the erest of the highest woralnal ridge in the county. The lake is in a small kettle hole rormed by the wasting of a sass of lee that was partly or wholly buried in the Arift. This lake is deeper than Cedar Lake and is fed by runoff frow local precipitation, effluent seepage of ground water, and from springs.

\section{Subsurface Deposits}

The subsurface glacial deposits consists of elayey t111, clay, silt, sand and gravel. Deposits in Lake County range in thlckness frow 50 to wore than 200 feet, with an 
average thickness of about 125 feet.

Clayey IIlls.- The tera clayey till is ased to group t11, sil, and clay under a general heading, as they are seldow differentiated by the driller. Blue, gray-blue, gray, yellow, brown, whd red clays are reported in the drillers" well logs.

The yellow, brown, and red clayey tills constitute only the upper part of the woraine and well logs show that they range frov thin veneer to a waximan of 60 feet in thickness. These yellew, browa, and red clayey tills are the deposite of the Valparaiso woralne left by the ${ }^{2}$ isconsin Lee aheet.

The gray-biue clayey till (gray, blue, or gray-blue) represents till laid down by older glacial advanees, prior to the deposits of the Valparaiso moraine. The gray-blue t111 Lies below the soll in several parts of the woraine but usually is overlain by the buff to yellow, silty, elay t111. The color of the clayey gray-blue till varies with the molsture content and depth. When wet the clays have a blue-black or deep graylsh-blue color and when dry the color changes to gray or light gray-blue.

The generalized cross sections (pls. 5, 6, and 7) show the vertical relation, lithology of the unconsolidated deposits, and their relation to bedrock. These sections show that two distinct deposits of clayey till are separated by a Layer of sand. Above the sand there are two separate 
tils; (1) a gray-blue clayey till which ranges in thickneas frow a thin layer to more than 100 feet, and (2) a capping of this gray-blue t111 by the yellow elayey t11. of the Valparaiso moraine. The older, undeted, lower til that lies below the sand is a gray-blue clayey til. The writer conslders the til. to be pre-lisconsinan, Mlinotan (?) in age. This till which 11 es on bedrock is separated from the younger Valparaiso till by glacial drixt which in places is over 150 feet thick. Two exposures of this Illinotan (7) t111 was observed on the calunet lake plain north of Mighland.

Samples of the gray-blue clayey till observed fros the upper and lower dcpostts are siallar in color and textare. The gray-biue elayey tils obtain their color froa the blueblack shale of Devonian age. The wain source of anterial for the Valparaiso voratne was the shales of the Lake Michigan basin and from the shales anderlying Lake County. The shale being relatively soft was easily broken and worn down to clay and silt wize and therefore, accounts for the lack of courae material.

In the cross sections (pla, 5, 6, and 7) the term "Undifferentiated drift (mainiy gray-blue clayey till)" is used. It is the opinion of the writer that the drift consiste salniy of gray-blue clayey til, interbedded with some sand and sravel lenses, and at the aurface the drift is probably Valparaiso till, a buff to yellow, silty, clay t111 
The data, recorts of wells and test boles, used in the cross sections (plis. 5,6 , and 7 ) can be obtained fros the Prelininary Neport: Lake County, Bulletin No. 10 (Rosenshein, 1961).

We11 No. 36/7w-19K1 is not given in that report because it could not be accurately located, as the well was destroyed during construction of a new subdivision. The author is of the opinion that the location is exact enough to be used for the cross sections.

The log of this well is given below:

Material $\begin{aligned} & \text { Thick- } \\ & \text { noss } \\ & \text { (feet) }\end{aligned}$ (feet) Repth

\section{quaternary Systen:}

Recent and pleistocene Series:

$\begin{array}{rrr} & & \begin{array}{r}\text { Altitude: } \\ 640 \text { feet }\end{array} \\ 5 & 5 & \\ 4 & 14 & \\ 46 & 60 & \\ 35 & 95 & \\ 35 & 130 & \\ 47 & 177 & \end{array}$

\section{Silurian Systeas:}

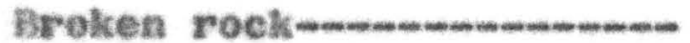

202 Dolonite or dolonitie 1 imestone

Band and Gravel.--The cross sections (pls. 5, 6, and 7) show that aheet-11ke deposit of sand and gravel lies beneath the Valparaiso woraine. This sheet-14ke deposit ranges in thickness from less than 3 reet to over 100 feet 
ahd underlies an area of about 250 square alles in Lake County. This sand deposit lies upon a gray-blue clayey till which the writer belloves to be pre-lisconsinan,

Iuinotan (?) in age, The sheet-like sand deposit was probably deposited during the retreat of the ice sheet which deposited the pre-wiseonsinan till and prior to the advent of the visconsinan glaciation. This deposit extends into Porter County on the east, inte XIIinois on the west, and crops out in the fenlkakee glaeiofluvial plain.

other amaller lenses or pockets of sand and gravel are interbedded in the drift or lie on bedrock. Well logs report sand and gravel at different levels. The sand and gravel in the glacial Arift is the chief source of ground water.

We11 logs any report muddy or dirty sand, indieating a silty or clayey sand. Drillers" information, well records, field examination of rock cuttings of the finished woll indicate that the sand and gravel deposits contain very little waterial coarser than pebbles. If further sawple studies verify the lack of coarse material, then the sand ast have been sorted from the coarser material and transported some aistance before being deposited. The source could be from the northeast.

\section{Kankakee Glaciofluvial Mlain}

In Lake County an area of about 95 square alles of 
gíclofluvial plain lies between the Valparaise moraine and the Kankakee River. In 1882 about 500,000 acres of swamp land reatined as evidence of a former lake in the IItankatiee Valley, 50,000 acres, of which were in Lake County (nlatchley, 1897, p. 56). Mach of the former warshland has been reelaited by extensive areining and is now under cultivation, The simuous Kankakee River has been straightened and leeves constructed along its bank to control Plooting. Within the county all the altehes and creeks that cross the plain eapty inte singleton Diteh, a parallel Arainageway. north of the Kankakee River. This ditch discharges its waters into the Kankakee River near Momence, IILinois. The valley of the Kankakee River begins in st. Joseph County to the northeast and extends westward to the DesPlaines River in northeastern Ilinois. Bredley (1870) stated that a large body of water which was called "Lake Kankakee" formeriy occupied wuch of the Kankakee Arainage basin. Bradey's "Lake Kankakee" oecupied aboat 3,000 square wlles of which 2,000 square miles were in Indiana (Barrett, 1916, p. 11). Leverett (1899, p. 338 and 1915, p. 128-130) opposed the theory that this large "Lake Kankakee" ever existed. He contended that only shallow lakes of gall extent oceupled parts of the Nankakee Valley. Leverett further stated that the lake whose waters once covered the large Wankakee warsh as reported by Blatchley (1897) extended only a short distance beyond the edge of this marsh. 
Ekblaw and Athy (1925, p. 18) in their studies of horthoastern IIInols agreed with Leverett and refuted the existence of a large lake in the Kankakee Valley. They concluded that the Kankghee Valley was a a jor drainageway for the melt waters of the Hchigan, the Saginaw, and the Erie Lobes of the 1 isconsin ice sheet; and that a groat torrent of clackal waters, called the "Kankakee torrent" (Ekblaw and athy, 1925, p. 419) had sufficient volute and velocity to erode a channel to considerable depth in the underlying glacial arift. At Monence, Illinois this torrent renoved about so feet of till and exposed the bedrock.

Upon further retreat of the ice sheet, new outlets were opened to the north that aiverted part of the selt waters entering the Kankakee Valley. Decause of the decrease in volume and velocity of the water, the heavily loaded meltwsater atreans aropped their load and deposited the sand and gravel in the Kankakee Valley.

Ekblaw and Athy (1925) reported that the "Kankakee torrent" is younger than the Minooks woraine in IIIInois. The Minooka woraine is older than the Valparaiso moraine (Leighton and illwan, 1953); although, both woraines were deposited during the woodfordian substage. This would indicate that the sand and gravel deposits in the Kanicakee Valley are slightiy older or conteaporaneous with the deposit of the Valparaiso moraine. However, the subsurface evidence in Indiano disputes, in part, this interpretation. 
Lines of cross sections in plate 5 show that the sheetlike deposit of sand and gravel that lies beneath the Valparaiso moraine extends Into the Kankakee glaciofluvial plain. 3. 3. Rosenshein of the U. 0 . Geological Survey and the writer have observed till overlapping the sand of the

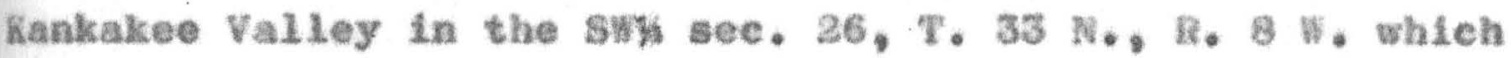
would indicate that outwash sand in the Kankakee Valley did not lap upon, but rather extended beneath the till of the Valparalso moralne. At least two glaclel advances followed the deposition of this sand and gravel. Therefore, the writer belleves that the sand and gravel beneath the Valparaiso soraine and in the lower part of the Nankakee glaciorluvial plain is pre-Wisconsinan, I1Linoian (7) in age. The sand and gravel was probably deposited during the rotreat of the ice sheet that deposited the IIInoian (?) till that lles upon bedrock. The suall glaclofluvial fans built off the Valparaise woraine in Lake County and the thin upper veneer of waterial deposited at the surface are probably the only woodfordian sands in the Rankakee glaciofluvial plain.

Surface Deatures

The Kankakee glaciof Iuvial plain alopes gently toward the Kankakee River. On this slope there are sall alluvial fans extending out into the Kankakeo Valley from the edge of the Valparaiso moraine and a few scattered sand dunes. 
Wóst of the dunes are small and are located between Sehnelder and shelby (pl, 2). Decause wuch of the area was warshland the sands were protected from wind erosion and only small dunes were built. The soll of the marshland is a darksandy loas, very rich in organic matter.

Dos iron in layers ranglng in thicknoss frow a thin veneer to about two feet and as coneretionary limonitic masses, was observed in several places along drainage ditches. About 185s, bog Iron was wined in the county and shipped to the smelter at Mshawaka (Logan, 1922, p. 763).

Subsurface Deposits

The anconsolidated deposits of the Kankakee glaciofluvial plain eonsist of sund and gravel with an average thickness of about 30 feet. Below the sand and gravel is a gray-blue clayey till which rests on bedrock and localiy is nore than 50 feet thiek. This till is probably of previseonsinan, Milnoian (?) in age.

The clayey thi thins toward the soutbwest and is missing in the extreme southwestern part of the county. The gray-blue clayey till was deposited upon a gently rolling bedrock surface of dolonitic linestone or dolonite of silurian age which slopes to the southeast (pl, 3). In the vieinity of shelby, the till overlies a thin remant of shale of Devonian age overlying roeks of silurian age (Line B-B?, pl. 5). 
About 5 feet of water-laid sand and gravel is exposed above the water table in a pit south of Lowell in the Swh. see, 1, T. 32 N., N. 9 W. This pit is excavated to a depth of about 35 feet. It is roported that there are some thin layers of blue elay interbedded with sand and gravel. Coarser waterials, ineluding cobbles and a rew boulders have been renoved from the lower part of the pit.

In the Nuh sec. 8, T. 32 N., R. 8 v, wand and sravel is obtained from below the water table. The owner reported that trees were found in parts of the pit at the water line, about 5 feet below the surface. At a depth of 15 to 20 feet boalders up to 4 fect in alameter were renoved froe the pit. Dr. William J. Wayne of the IndLana Geological Survey, (oral comanication) reported that, in an abandoned pit in

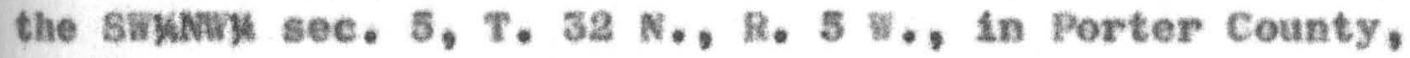
wood was found buried beneath 5 to 6 feet of gravel. A radiecarbon date of $7,900 \pm 200$ years B.P., deterained by the U.S. Geologieal Survey $(W-59)$ was given for the age of this wood. This suggests that the send and gravel covering the wood was deposited during the valderan substage. It does not appesr reasonable that the late 1 sconsinan deposits should be found in the Karikakee Valley. More radiocarbon dating is noeded to establish the age of the upper sands in the Kankakee Valley. 
chowNo WATSR

Consolldated Deposits

General principles underlying the source, occurrence, and arvement of sround water have been described by Meinzer (1925) and others. Ground water in consolidated rocks is stored in the openings, such as joints, fissures, solution cavitles and pore spaces. These openings or interatices range in tise from very anal openings (mieroscople) to large openings, such as ceverns. The quantity of water that can be obtained froa consolidated rocks depends on the size of openings and degree of intercomections.

\section{Deep lock Aguirors}

In Lake County several wells have been arillea Into the deep rock aquiferg of Canbrian and ordovician age. The three wells that obtain water fros these agaifers have low ylelds and produce highly alneralized water (table 5). Therefare, the deep rock aquifers are considered to be a poor source of water.

\section{Shallow Rock Aguiferg}

Wiagaran rock of Midie silurian age is the wost prom ductlve shallow rock agaifer. A rew wells obtain water from the shale of Devonian age. The rocks of Devonian and glurian age are recharged asalnis frow the water-besing sand and gravel in the overlying glaelal drift. 
Table 5,-Welected chendeal analyses of water in Lake County, Indiana. (in parts per willon, except, pli. Wemarks: 1, induetry; M, muleipuilites, public supply; $\mathbf{L}$, Lake Mlchigan; $\mathbb{N}_{\text {, not ased as }}$ publie supply; he, deep roek aquifers: tas, shalLow rock aquifers; Sd, and and rravel).

\begin{tabular}{|c|c|c|c|c|c|c|c|c|}
\hline Location & Well No. & Use & $\begin{array}{l}4 \\
0 \\
1 \\
3 \\
0 \\
\end{array}$ & 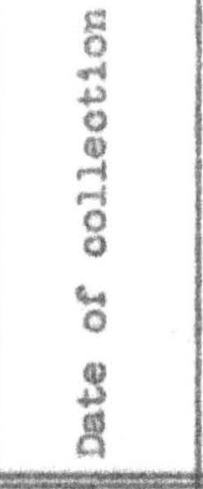 & 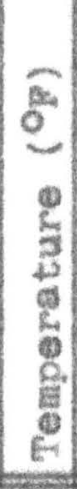 & 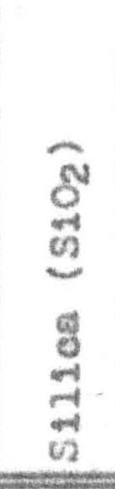 & 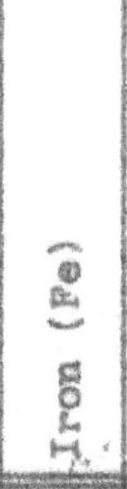 & 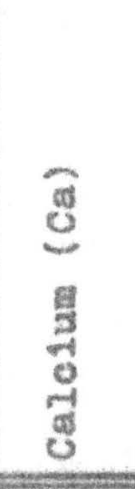 \\
\hline East Chlcago & $37 / 96-28131$ & 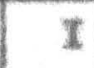 & nd & $6-24-54$ & 50 & 9.6 & 0.29 & 213 \\
\hline Gary & $36 / 9 N-24 C 1$ & I & Rd & $6-16-54$ & 68 & 8. & 1. 1 & 273 \\
\hline Seherervilide & $55 / 92-1501$ & M & Ass & $2-6-58$ & - & & 1.2 & 102 \\
\hline Dyer & $55 / 10 \mathrm{~W}-1 \mathrm{scd}$ & M & Res & $4-3-59$ & - & & 2.6 & 105 \\
\hline Lowe 11 & $33 / 9 n-23 \times 2$ & M & ass & $2-6-58$ & - & & .2 & 12 \\
\hline Sehneter & $52 / 9 N-3401$ & M & tis & $2-6-58$ & - & & .3 & 66 \\
\hline Cast Gary & $36 / 7 \%-1642$ & $M$ & sd & $5-20-39$ & - & & .4 & 52 \\
\hline New Chieago & $36 / 7 w-21018$ & $M$ & sd & $9-19-57$ & - & & 0 & 48 \\
\hline Grifrith & $35 / 9 w-2 c 1$ & $M$ & sd & $6-3-54$ & - & & 2.4 & 73 \\
\hline Crown Polnt & $34 / 81-512$ & $M$ & $\operatorname{se}$ & $6-18-58$ & 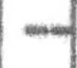 & & 3.2 & 116 \\
\hline Shelby & $32 / 81-2842$ & $N$ & sad & $5-26-59$ & - & 12 & 7.5 & 124 \\
\hline Dlaswand & & M & if & $3-20-54$ & - & - & 0 & - \\
\hline Gary & & M & 4 & $11-2-34$ & - & & .00 & 33 \\
\hline
\end{tabular}

a/ U. S. Geological Survey.

b/ Indiana state Board of lealth.

of Gary-lobart water Corp., by Company chendet. 
Table 3.--Contlinued

\begin{tabular}{|c|c|c|c|c|c|c|c|c|c|c|c|}
\hline & & & 8 & • & & & gृ & $\begin{array}{r}\text { Hardin } \\
\text { cac }\end{array}$ & $\begin{array}{cc}88 & a s \\
3 & \end{array}$ & & \\
\hline 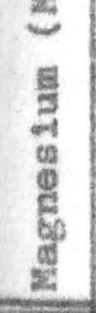 & 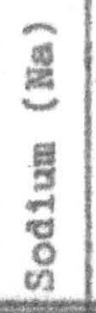 & 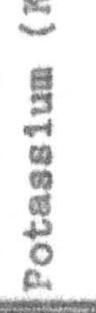 & 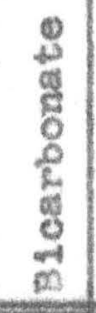 & $\begin{array}{l}3 \\
0 \\
0 \\
-1 \\
0 \\
\frac{1}{0} \\
\frac{1}{0}\end{array}$ & 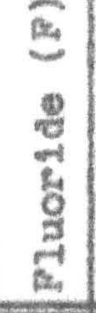 & 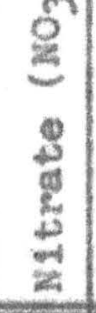 & 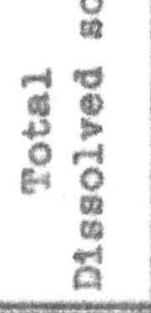 & 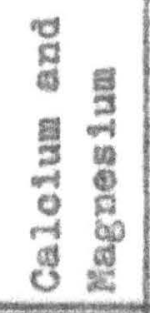 & 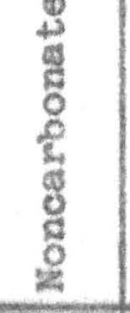 & p. & (4) \\
\hline 53 & 392 & 22 & 285 & 402 & 2.8 & 0.6 & 2,008 & 752 & 516 & 7.2 & \\
\hline 101 & 774 & 31. & 256 & 1,130 & 2.4 & 5.4 & 3,409 & 1.098 & 887 & 7.7 & \\
\hline 64. & 80 & 6 & & 6 & .3 & 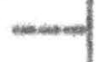 & $-\infty$ & 518 & $-\infty$ & 7.3 & \\
\hline 71 & 46 & 5 & & 6 & .4 & & - & 555 & $-\infty$ & 7.9 & \\
\hline 8) & 216 & 8 & & 75 & 4.4 & & - & 64 & $m-$ & 5.4 & \\
\hline 29 & 74 & 10 & & 52 & .9 & - & $-1-\infty$ & 284 & -1 & 7.5 & \\
\hline 18 & 5 & 2 & & 8 & 0 & & $-\infty=-10$ & 204 & $-\infty$ & 8.1 & \\
\hline 15 & 4 & 1 & & 4 & .1 & - & - & 284 & $=$ & 7.8 & \\
\hline 43 & 23 & 2 & & 6) & .2 & - & $-m-m$ & 560 & $-\infty$ & 7.8 & \\
\hline 49 & 15 & 2 & - & 14 & - 1 & - & - & 490 & - & 7.8 & \\
\hline 48 & 20 & 7. & 360 & 44 & 0 & 4 & 605 & 482 & 187 & 7.1 & \\
\hline & & & & -1 & 0 & 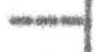 & $-\infty$ & 130 & $-\infty$ & Q.2 & 2 \\
\hline 11. & 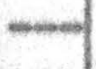 & & - & 8 & .1 & -2 & $-m-\infty$ & 131 & 16 & 8.2 & \\
\hline
\end{tabular}


According to Arillers" records the rock of silurian age underlying the caluwet lake plain is a dense, tight Iinestone and wells orilled into the rock do not yield large quantities of water, however, sufficient water can generally be obtained locklly fron this source for domestie use. South of the Calumet lake plain the rock of SLlurian age apparently is more poreeable and well ylelds are higher. Five aunicipalities; Dyer, Lowell, Schererville, Schneider, and st. John have wells and obtain their water supply from this aguifer. In addition, several industries, wany households and rariss obtain water from this roek source.

The water from the sLiarian and Devonian rock acquifers is tsually very hard. The average hardness of water is about $270 \mathrm{ppm}$, and ranges fron 20 to $650 \mathrm{ppm}$. Selected andyses of water frow the shallow rock aquifers are given in table 5. About one-third of the water analyses ahow wore than 0.3 ppa iron which is usually objectionable. "Sulphar" water is conases. To avold "sulphur" water in some lecalities the doestic wells are drilled only a few feet Into the roek. Deeper rock wells in the area always eontain "sulphur" water.

Unconsolidated Deposits Ground water is obtained from the unconsolidated glacial sand and gravel. The quantity of water avallable from a saturated sand and gravel aguifer depends upon the 
size and interconnection of the pore spaces.

\section{Becharge}

The ground-water reservoir in Lalke County is recharged from local precipitation. The sandy areas of the Calumet lake plain and the Kankakee glaciofluvial plain are the most favorable areas of recharge. In the area of the Valperaiso moralne, the soll foraed aninly from clayey till impedes the infiltration of water into the ground and recharge is less favorable. However, slow recharge occurs on the moraine, as the surface is flat to wederately rolling, and runofe frow precipltation is not rapid.

Discharise and Guilization

Ground-weter discharge takes place by natural and artificisl means. Under natural conditions ground water is aischarged near the surface by evapotranspiration, by seepage and apring flow into streags and lakes, and by wigration to distance points of discharge. Ground water is discharged artifieially by punping of water wells and drainage into ditches.

Several thousand acres of land are drained by ditches that lower the ground-water levels and rewove excess surface water. The largest drainage project is on the Kankakee glaclefluvial plain where many hundreds of acres of marshland have been reclaimed. where natural drainege con- 
ditions are poor on the Calumet lake plain and on the Valparaise woraine, the land is arained artifieially by ditches. The slope or hydraulic gradient of the piesosetrie surface (pl. 8) shows that a ground-water divide colneides closely with the land surface aivide. Netural ground-water discharge is toward Lake Michigan on the north and toward the Kankakee River on the soath.

Ground water obtained fros sand and gravel to the wost important source of water for household and fare wells in Lake County. Several wunieipalities and industries obtain water rros the sand and gravel; Crown polnt, Nast Gary, and New Chicago are the largest usera. Until recently, Crifrith used ground water for its public water supply.

The ground water from the sand and gravel in Lake County is generally harder than that obtained from the shal10w rock aguifers. The hardness ranges from about 170 to more than 1,000 ppe.

Most of the water from the sand and gravel contalns aore than $0.3 \mathrm{ppm}$ iron. The average iron content is about 2.0 ppa and vanges froa leas than 0.1 to 7.5 ppin. Selected analyses of water froe the sand and grovel are given in table 5. 


\section{SUPACE WATE}

Nearly all the surface water used in Lake County is obtained fron Lake Michigan. Because of the nearness to this abundant supply, of lake water, many industries have located on the Calumot lake plain. Besides the large quantities of lake water used by industries, the eities of last Chieago, Gary, Griffith, Matanond, Mighlend, Mohart, Munster, and whing wae Lake Michigan as their source of public water supply. The streass, sabil lakes, and ponds in the county supply some water, mainly for watering stock.

The water fros Lake Michigan is sefter and contains

less iron than the ground water. The hardness of the lake water averages about 130 ppm and the iron content is less then 0.3 ppin. (See table 5.) 
sonemax

Lake County is in the northwestern corner of Indiana and has an area of about 517 square ailes. The county is divided into three physlographic anits: the Caluact lake plain, the Valparaiso woraine, and the Kankakee glaciofluvial plain.

The Calamet Iake plain was covered by daclal Lake Chicago, and beach Ines; the Glenwood, the Calumet, and the Tolleston show phases of the lake's history. Siand dunes cover a large portion of the plain and in the northeast, dunes rise more than 150 feet above the level of lalke Mchlgah.

The Valparaiso end moralne trends east-west across the county and is about 16 siles wide. The Continental Divide follows along the crest of the moralne. North of this crest is a sealler ridge that is correlated with the rinley thoraine in Milinols.

The Fankalce elaciofluvial plais is about 5 miles wide and has a gentie slope frow tho Valparalso woralne to the Iankakee Niver. This plain, formerly urshland, has been drafned and is now under cultivation.

The bedrock surface ranges in elevation from about 625 feet to 450 feet above mean sea level. The general sope of the bedrock surface is frota the southwestern part of the county toward the basin of Lake Michigan. Pive preglacial stream valieys enter Lake county from a bedrock drainage 
divide in ruluois and pass into the basin of Leke Melugan.

A gray-blae clayey till averaging about 50 feet in thickness overlies the bedrock surface and is considered to be pre-wiseonsinan, Illinoian (?) in ago. Sabd and gravel ranging in thickness frow a thin veneer to wore than 30 feet, and thin lake deposits overlie this till in the Calumet lake plain. Overlying the till in the realaining part of the county is a sheet-like deposit of sand and gravel that rapges in thickness from less than feet ta over 100 feet. This sheet-like deposit, Mllinolan (?) in age, Iles beneath the Valparalso woralne and crops out on the surface of the franktatree glaciof luvial plain. The upper part of the outwash on the Kankakee glaciofluvial plain was probably deposited during the woodfordian substage.

Two distinct tilis were deposited upon this sand and gravel in the area of the Valparaiso moralne. The lower t11. is a gray-blue clayey till asilar in appearanee and texture to the gray-blue clayey till lying apon the bedrock. The apper till is a buff to yellow, silty, ellay lill of the Volparaise and Tinley aoraines which was deposited during the woodfordian substage.

Cround water is the source of water supply in the Valparalso teraine and the Kankakee glaciofiuvial plain. Surficient quantitios can be obtained to supply seall manielpelities. The ground water is generally very hard and 
usualiy contalns an objectionable amount of iron. Deep rock aguifers are a poor source of water because of high wineralization and low yield. Large quantities of goed water from Lake Mchigan supplies the water for the Andustries and wanleipalities of the Calunet lake plain. 


\section{SRLECTRD DIRLIOGRAPKY}

Athy, L. P., 1928, Geology and ineral resources of the Werscher quadrangle: MIInode Geol. Survey Muld., 55, 130 D.

Barrett, sdord, 1916, The dunes of northwestern Indiana:

IndLana Dept. Geology and Wat. Mesources, 4lst Ann. kegt. D. 1.1-37.

Bieber, C. L., and Smith, N. M., 1952, Industrial sande of the Indiana dunes: Indiand Dopt. Conerv, Cool. Survey bul1. 7, 31 p.

matchley, W. S., 1897, Geology of Lalce and forter countles: Indiana Dept. Coology and Nat. Nesoarces, a2d Ann. Rept., p. $35-104$.

Bradley, F. H., 1870, Geology of frandy, w11, Kankakee, Iroguels, Vernilion, Champatgn, Ragar and Ford Counties In Illinole. MLinois Geol. Survey, v. 4, p. 227-230. Breta, $J .1 \%, 1039$, Geology of the Chicago region: pt. I, General: MLInols Neo1. Survey Bul1. 65, 118 p. 1951, The stage of Lake Chicago-their causes and correlations: Aata Jour. Set., v. 249, no. 6, p. 401-4a9. 1955, The pleistocene, pt. a of geology of the chicarro region: IIInols Gool. Survey Dull. 65, 132 p.

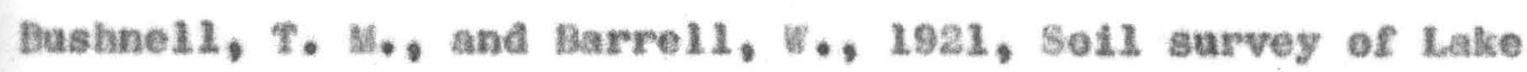
County, Indiana: U.S. Dept. Agriculture, Bur, of Solls, 48. P. 
Cressey, G. B., 1928, The Indians sand dunes and shore lines of the Lake Michigan Basin: Geog. Soc., Chicago, Bull. 8, 80 p.

Eardley, A. $J_{*}, 1051$, structural geology or North Ameriea: Now York, Harper and Brothers, 624 p. Ekblaw, 6. E., 1938, Kankakeo areh in H1Lnols, Geol. Soc. Aaerica Bull., v. 49, no. 9, p. 1425-1430. Ekblaw, 6. F., and Athy, L. F., 1925, Glacial Kankakee torreat in northeastern Mlinois: Geol. See. Atwerica Bull., v. 36, no. 2, p. 417-427. Fenneman, N. M4, 1938, Physlography of eastern Dnited states; New York, MeCraw-HA11, 714 p. Flint, R. $P_{*}$, and Deevoy, E. S., Jr., 1951, Radiocarbon Aating of late-pleistocene events: Am. Jour, Sci., v. 249, no. 4, p. 257-300.

Flint, R. F., 1957, Glacial and Pleistecene geology: New York, John wHey and Sons, $35 s$ p. Frye, 3. C., and wiliman, H. B., 1960, Classification on the Waconsinan stage in the Lake Miehigan glacial lobe: I1Inols state Cool. Survey Circ. 285, p. 1-16. Freenan, L. B., 1951, Negional aspects of Sllurian and Devonian subsurface stratigraphy in Kentucky: Als. Assoe. Petroleus Geologists Full, v. 35, no. 1, p. $1-61$.

Cutstad, A. M., 1958, Cambrien and Ordovieian stratigraplyy and oll and gas posisibilities in Indianat Indiane Dept. Conserv, Ceol, Survey Eul1, 14, 103 p. 


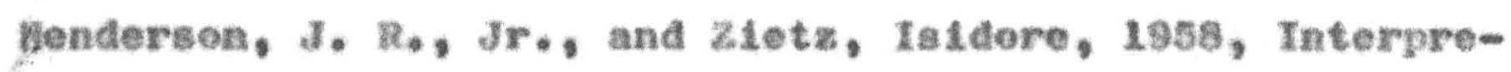
tation of an aeroaagnetie survey of Indians: $U .5$. Geol. Survey Prof. Paper 316-19, 37 p. Horberg, Leland, 1856, Bedrock topography of ILInots: IIInols Geol. Survey Bull. 73, 111 p., pls. 1, 2. hough, J. L., 1938, Geology of the Great Lakes: Urbana, Univ. IMinols Press, $313 \mathrm{p}$.

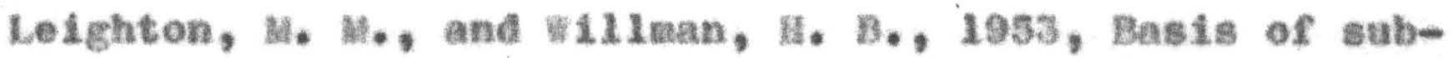
Aivisions of Hiscomsin Giacial stage in northesstern Minois, in Friends pleistocene Midveat Sec.: Cuidebook, 4th Field Conf., p. 1-98.

Leverett, Frank, 1899, The IIIInois glacinl lobe: 4.8 . Ceol. Survey Mon. $38,817 \mathrm{p}$. Leverett, Frank, and Taylor, F. B., 1915, the Pleistocene of Indina and wehigan and the histery of the Great Lalaes: v.S. Gwol. Survey Mon. 53,529 p. Logab, N. N., 1922, Leonomic geology of Indiana, pt. 5 of Wandbook of Indlana geology: Indlana Dept, Conserv., Div, Ceology Dab. 21, p. 571-1038. 1931, The subsurface strata of Indiana: Indiana Dept. Conerv., Div. Geology Mub. $103,790 \mathrm{p}$. malott, C. A., 1922, the physiography of Indiana, pt. 2 of Handbook of Indlana geology? IndLane Dept, Conserv., Div. Geology Dab. 21, p. 59-256.

Meinzer, 0. $0 ., 1923$, The occurrence of ground water in the United States, with a discussion of principles: Geol. Survey Water-5upply Paper $489,321 \mathrm{p}$. 
Pettijotin. F.J., 1931, Potrography of the beach sand of southern Lake Michigan: Jour. Ceology, v, 39, \$. 432485.

1949, Sedimentáry rocks! New York, Marper and Brothers, $526 \mathrm{p}$.

Rosenshein, J. \$, 1961, Ground-water resources of northwestern Indiena, prolininary report: Lake County: Indiana Dept. Conserv., Div. Water Nesources Bull. 10, 220 p.

Suter, Max, and others, 1959, Preliainary report on groundwater resources of the Chicago region, Illineis: IILinols water Survey and IILinois Geol. Survey Cooperative fround-water Rept. 1, 89 p.

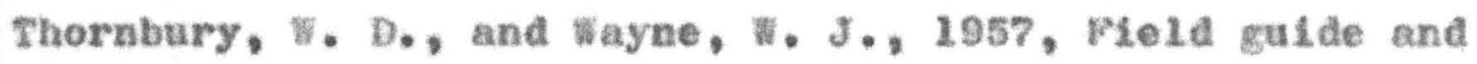
road $\log$ for study of Kansan, Illinoian, and early Tazewell tills, loesses, and associated faunas in south-central Indiana: Midwestern Friends pleistocene Guidebook, 8th Fiold Conf., Eloosington, Indiana Univ., 27 p.

Thornthwaite, c. $w_{\circ}, 1948$, An approach toward a retional classifleation of cllmate. The Geog. Rev., v. 38, p. $55-94$. Visher, S. 5., 1944, Climate of Iadiana: Indiana Vniv. Pub. Sc1. Series 13. 
Whane, 露. J., 1956, Thickness of Arift and bedrock physiography of Indiana north of the Fisconsin glecial boundary, Indiana Dept. Conserv., Geol. Survey Rept. of Proge 7, 70 p.

Zumberge, J. H., and Potzer, J.E., 1956, Late ${ }^{5}$ isconsin chronelogy of the Lake Michigan Das in correlated with pollen studiest Geol. Soc. Amerlea Bull., v. 67, no. 3. p. 271-288. 


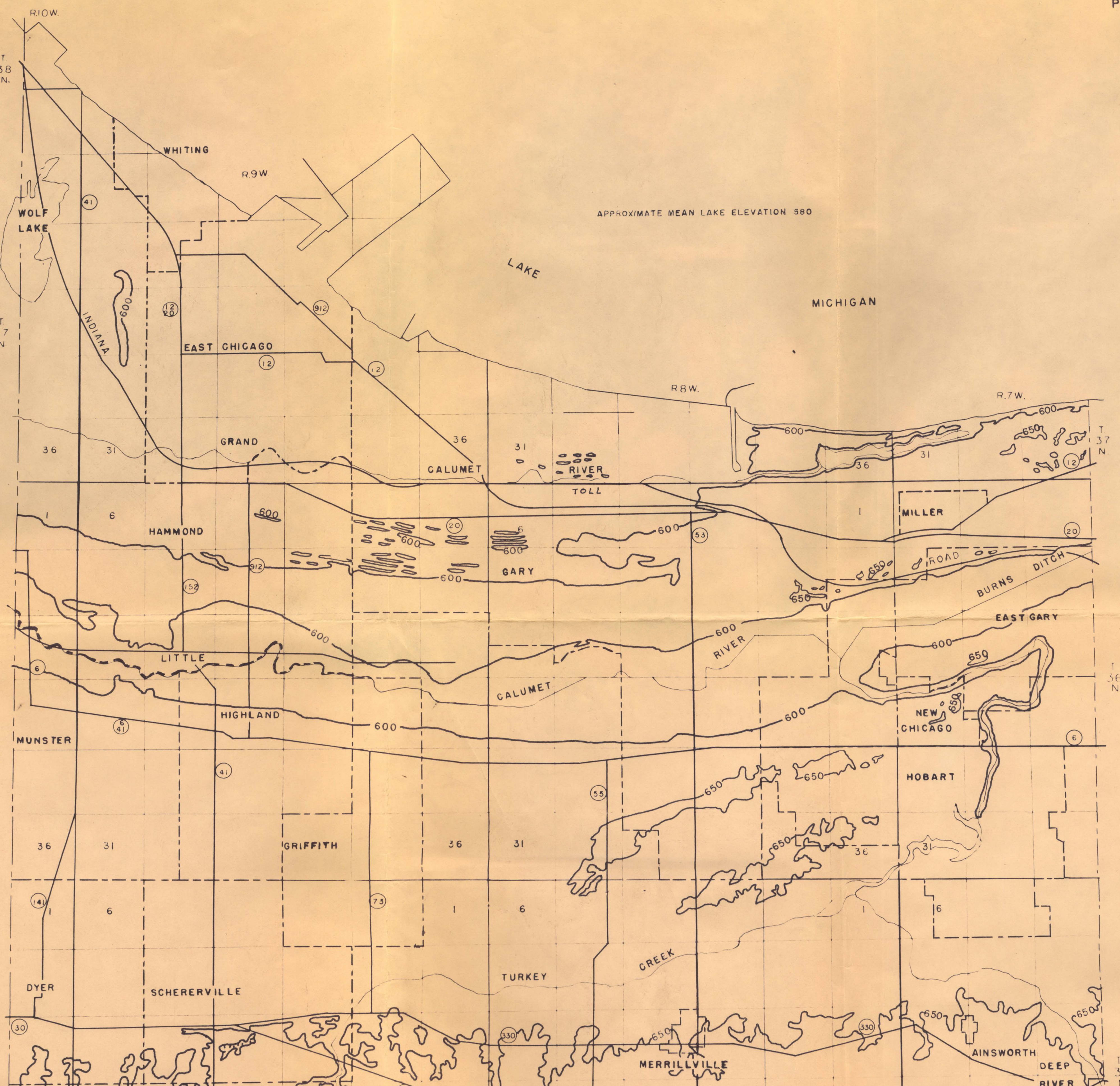

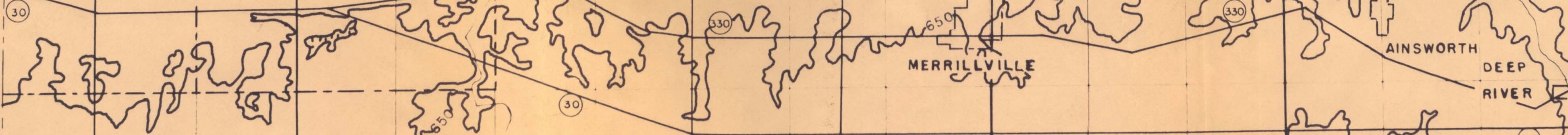

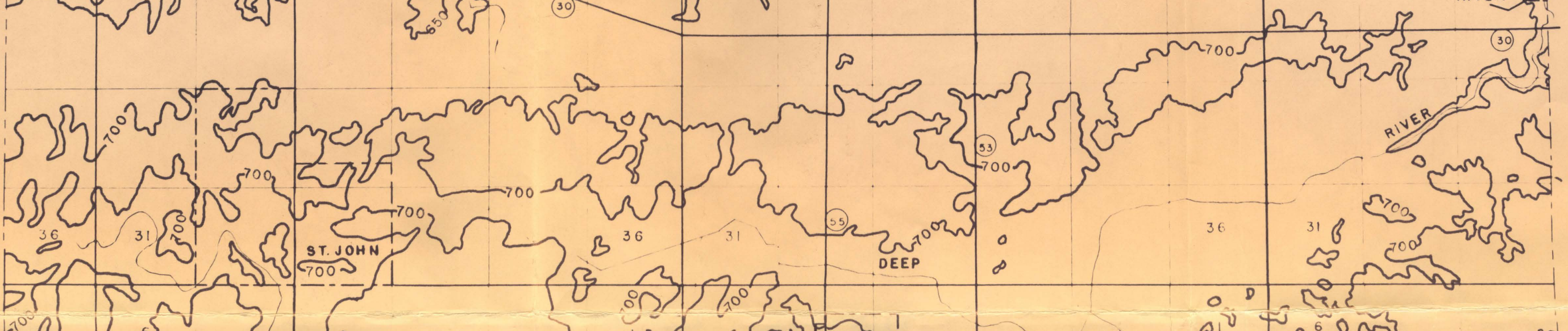

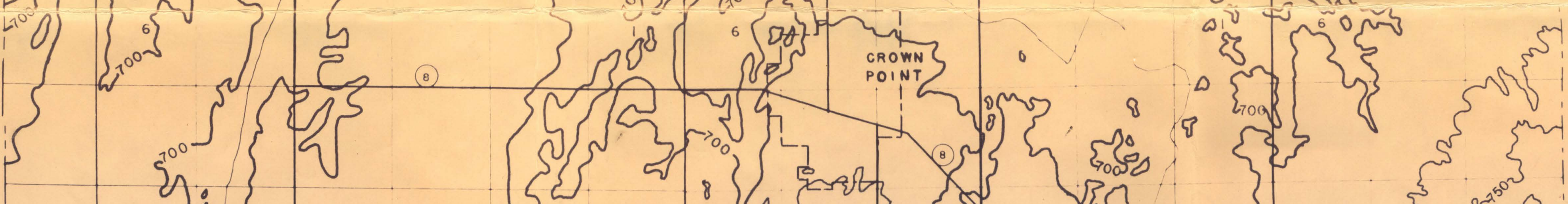
年 N 250 \{

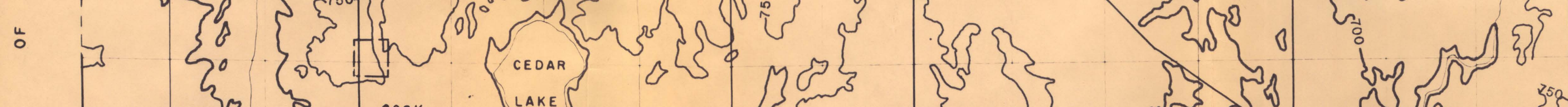
至

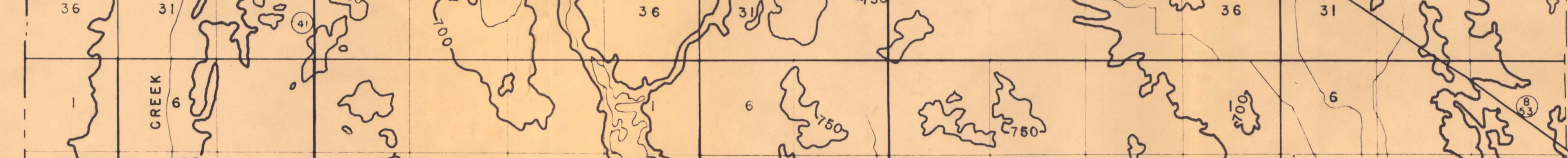
\{ 300 is

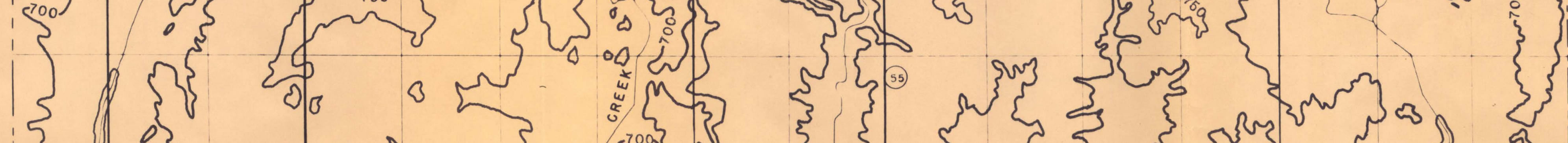

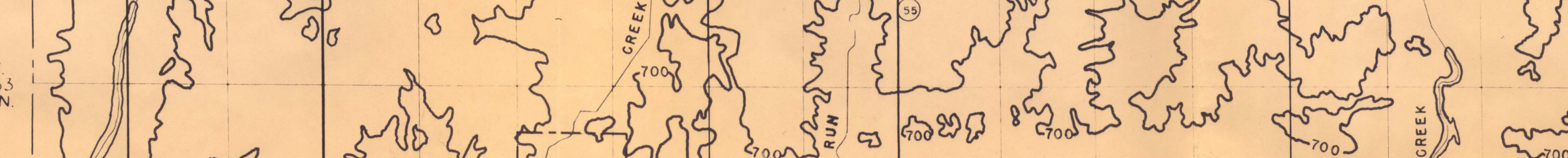

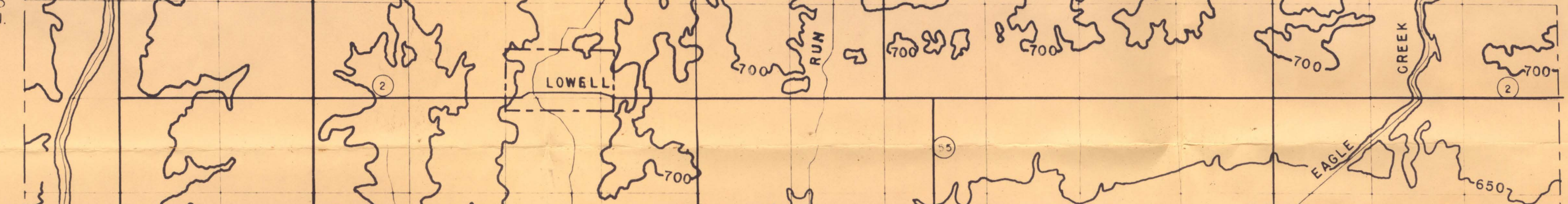
3)

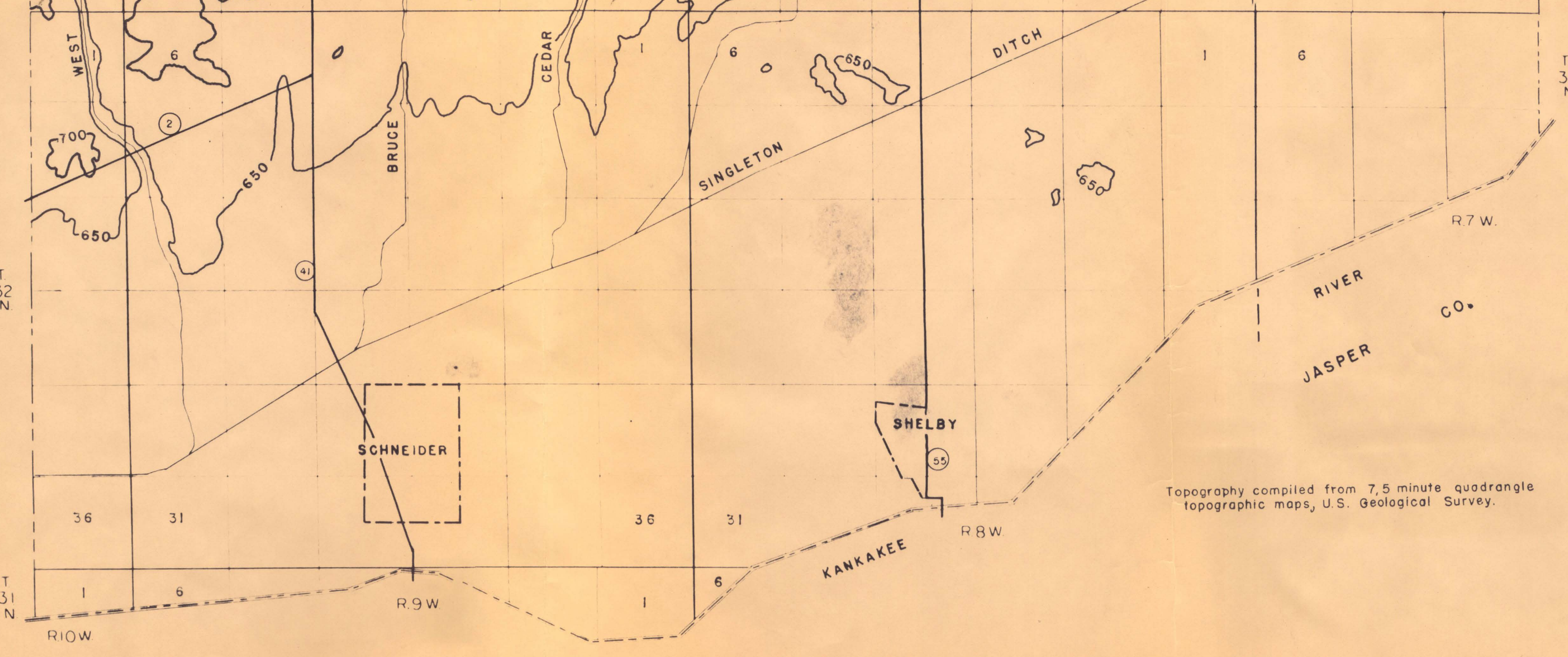




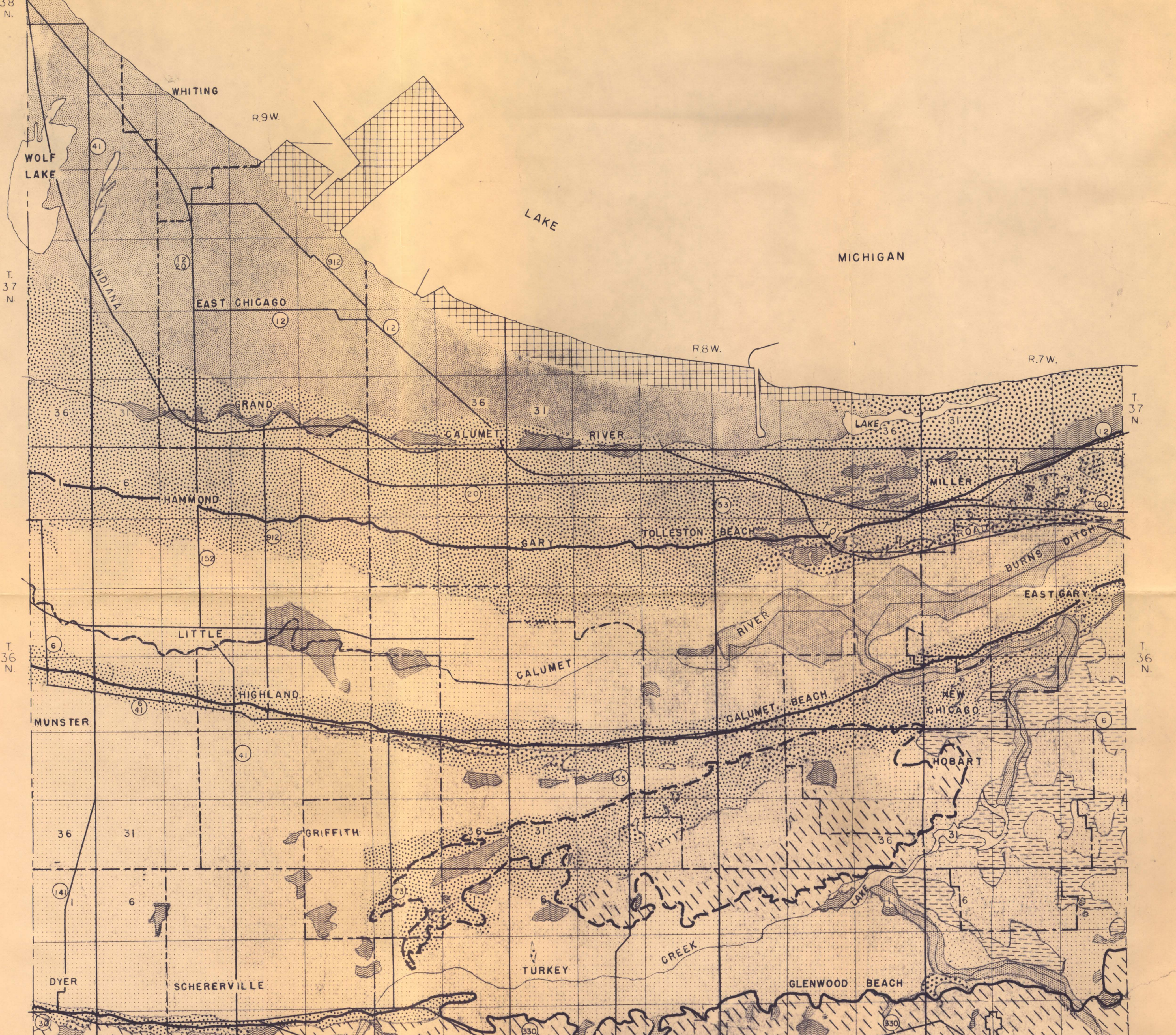

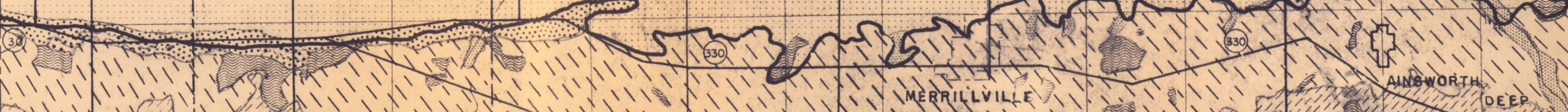
.

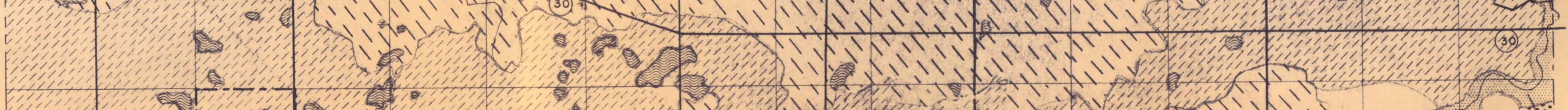

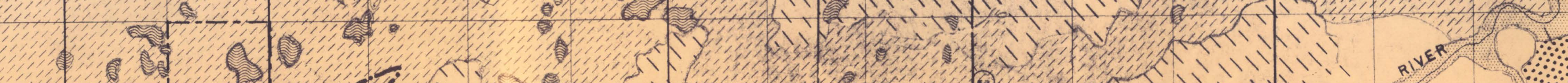
-

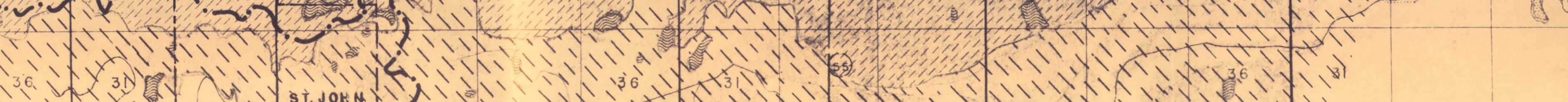
11

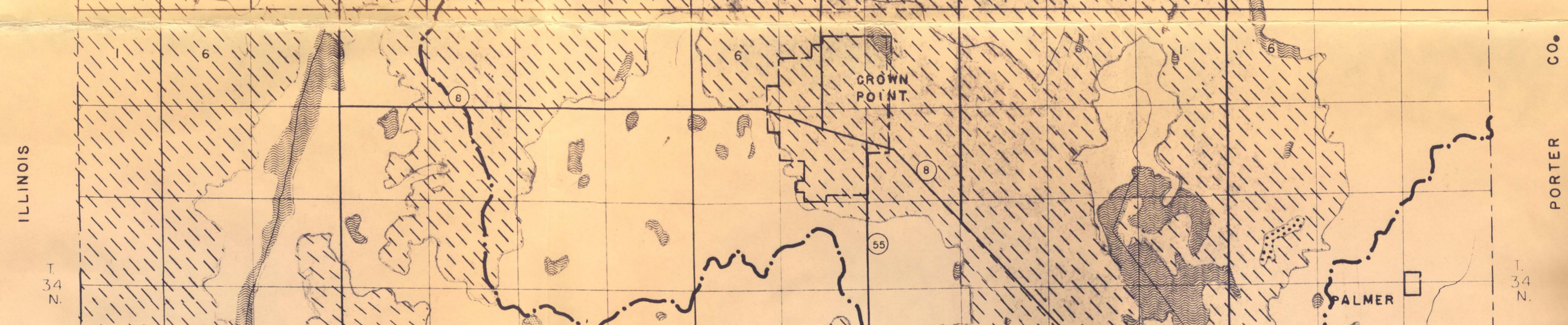

hititint

势

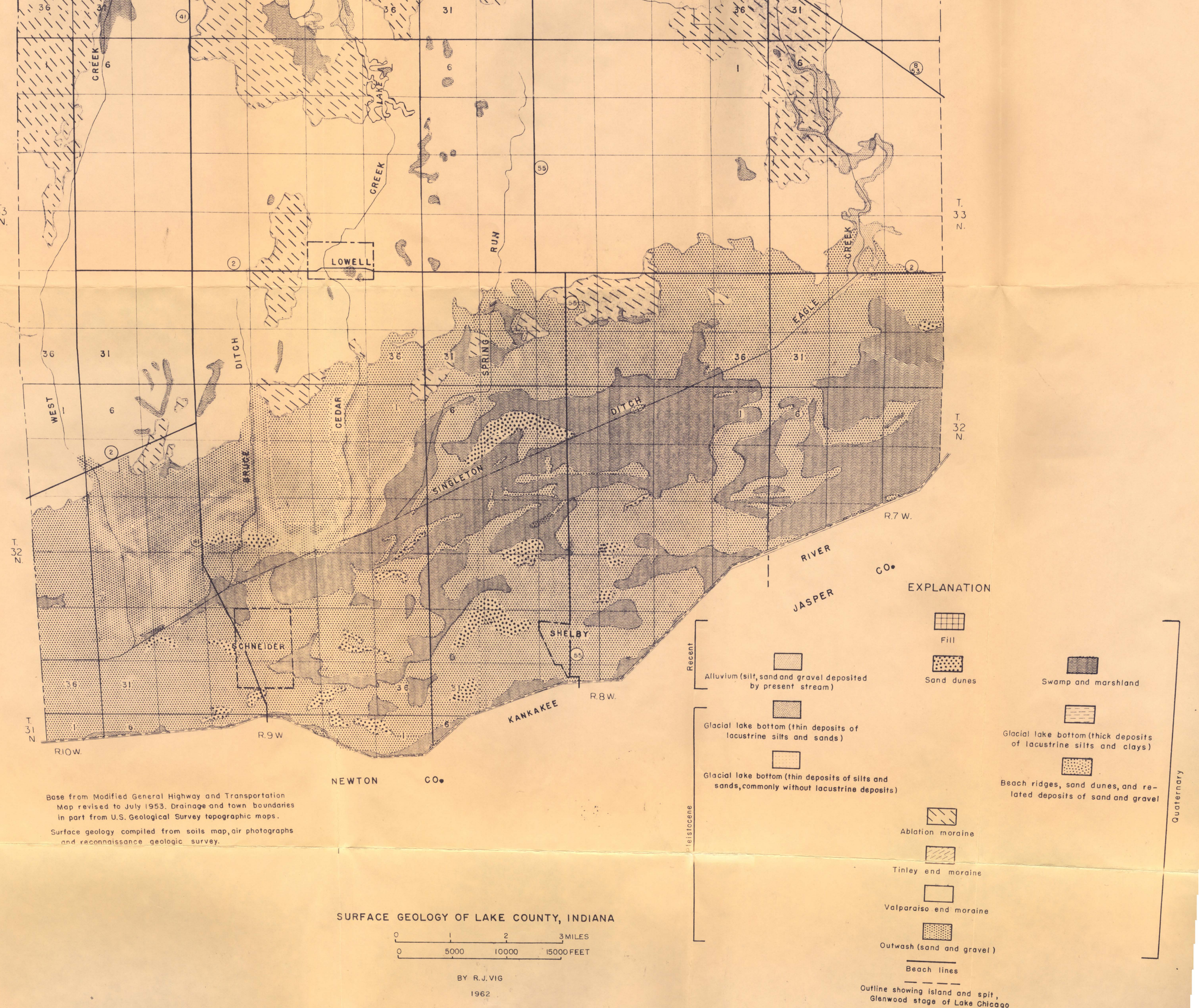




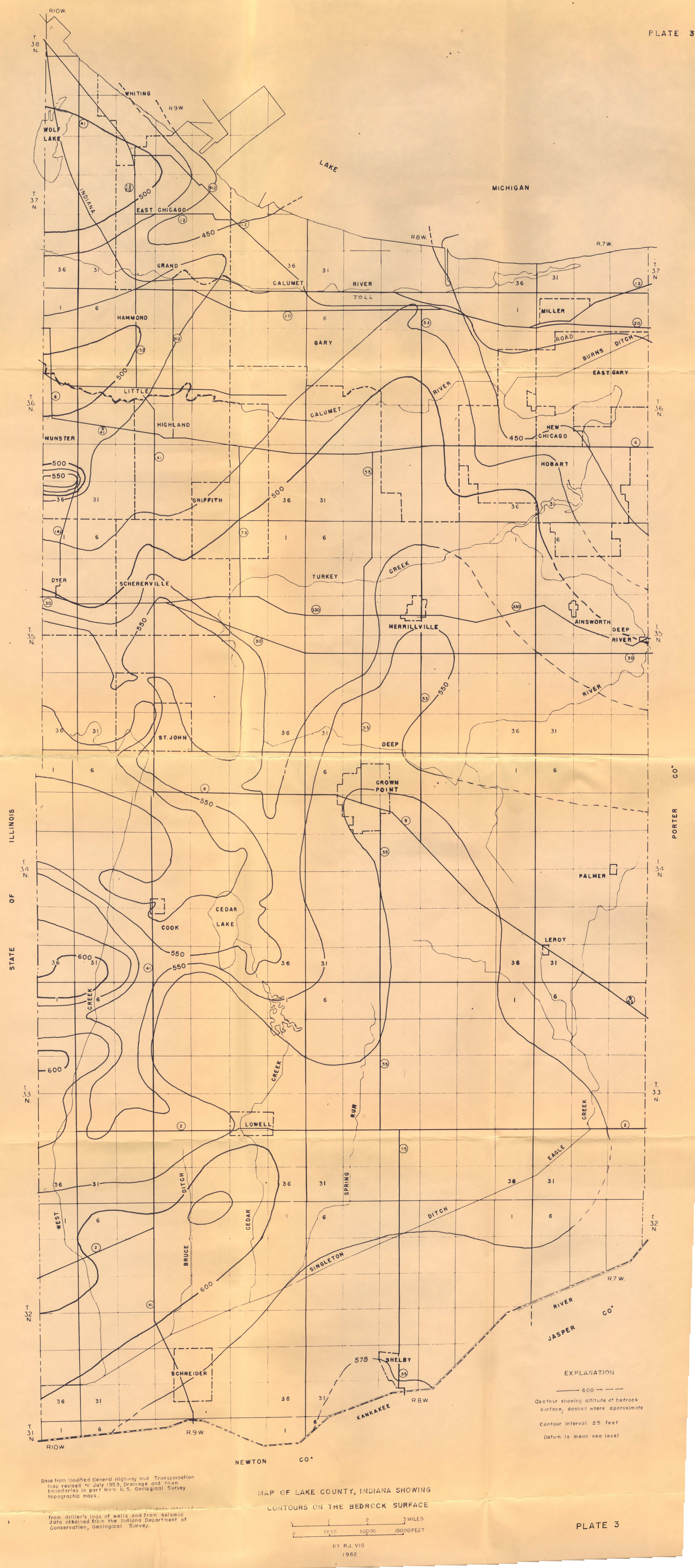




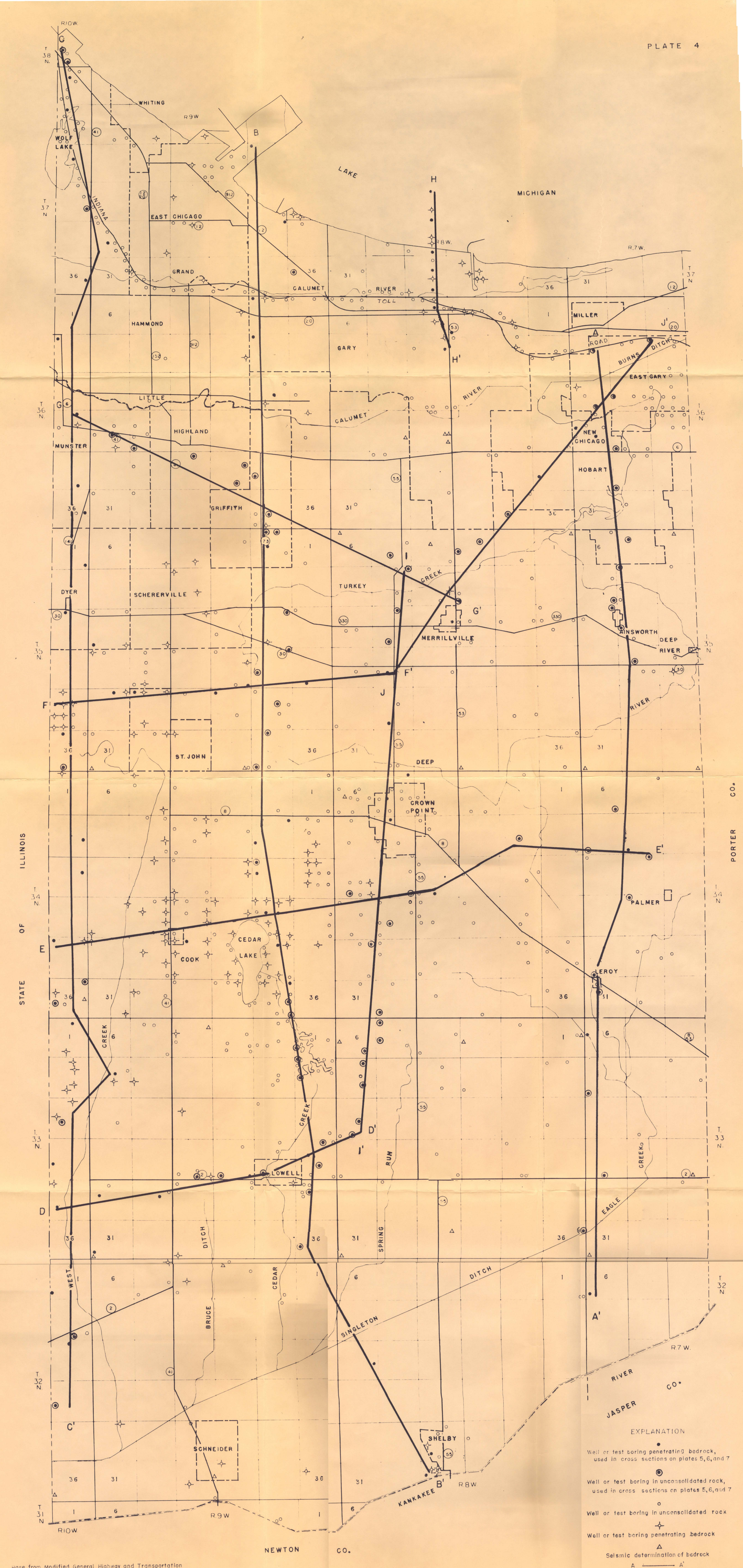




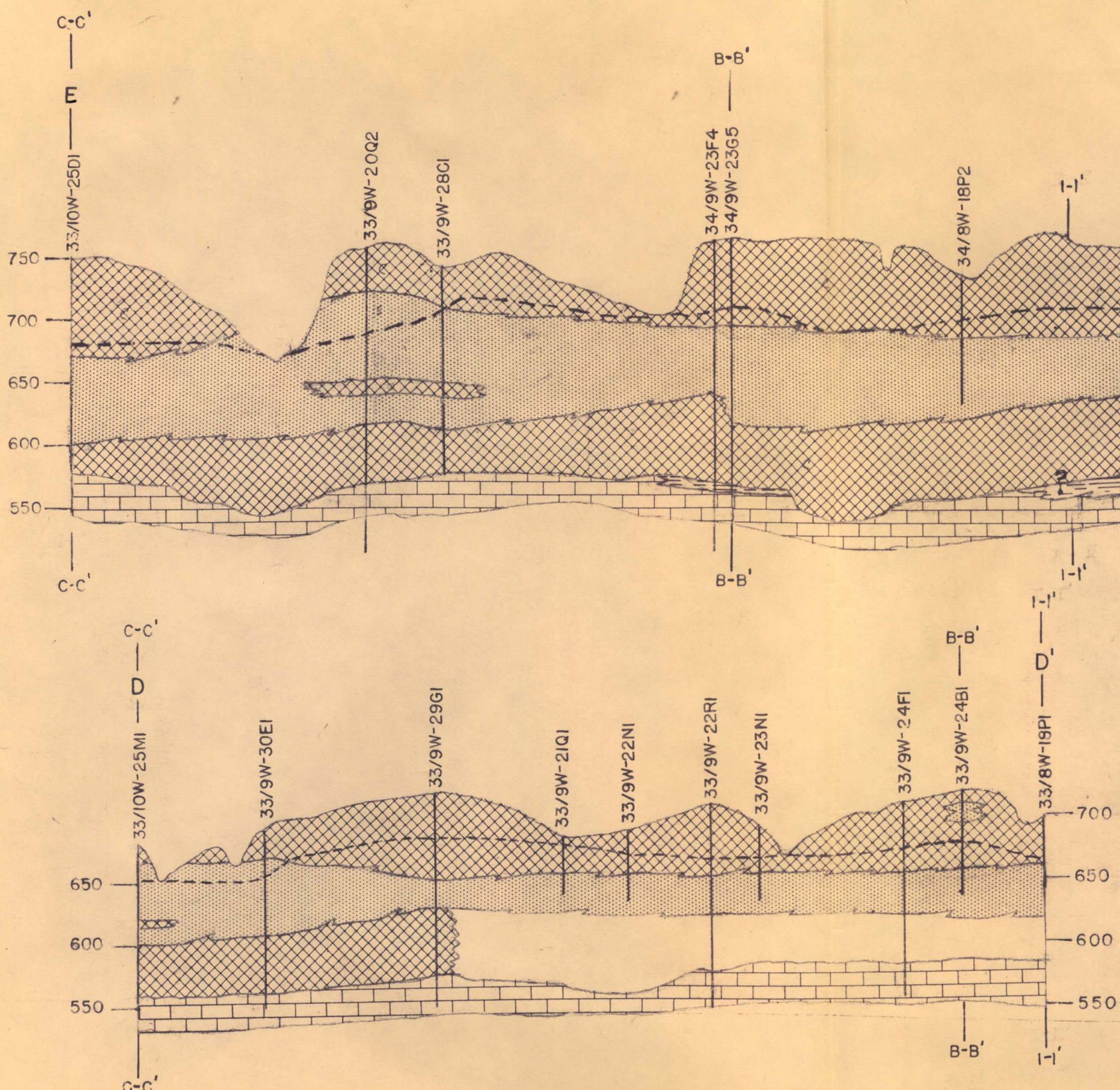

SECTIONS SHOWING GENERALIZED GEOLOGY

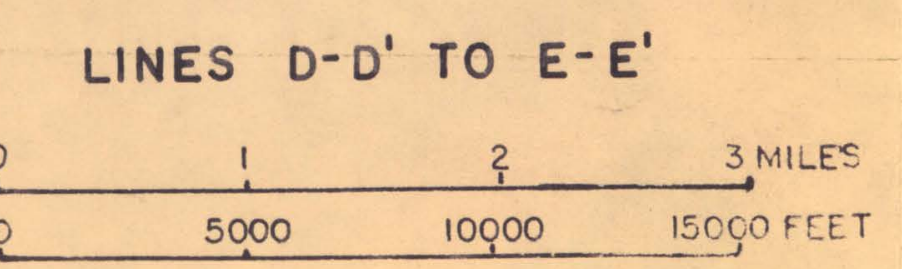

VERTICAL EXAGGERATION 50 TIMES

DATUM IS MEAN SEA LEVEL

BY R.J. VIG 

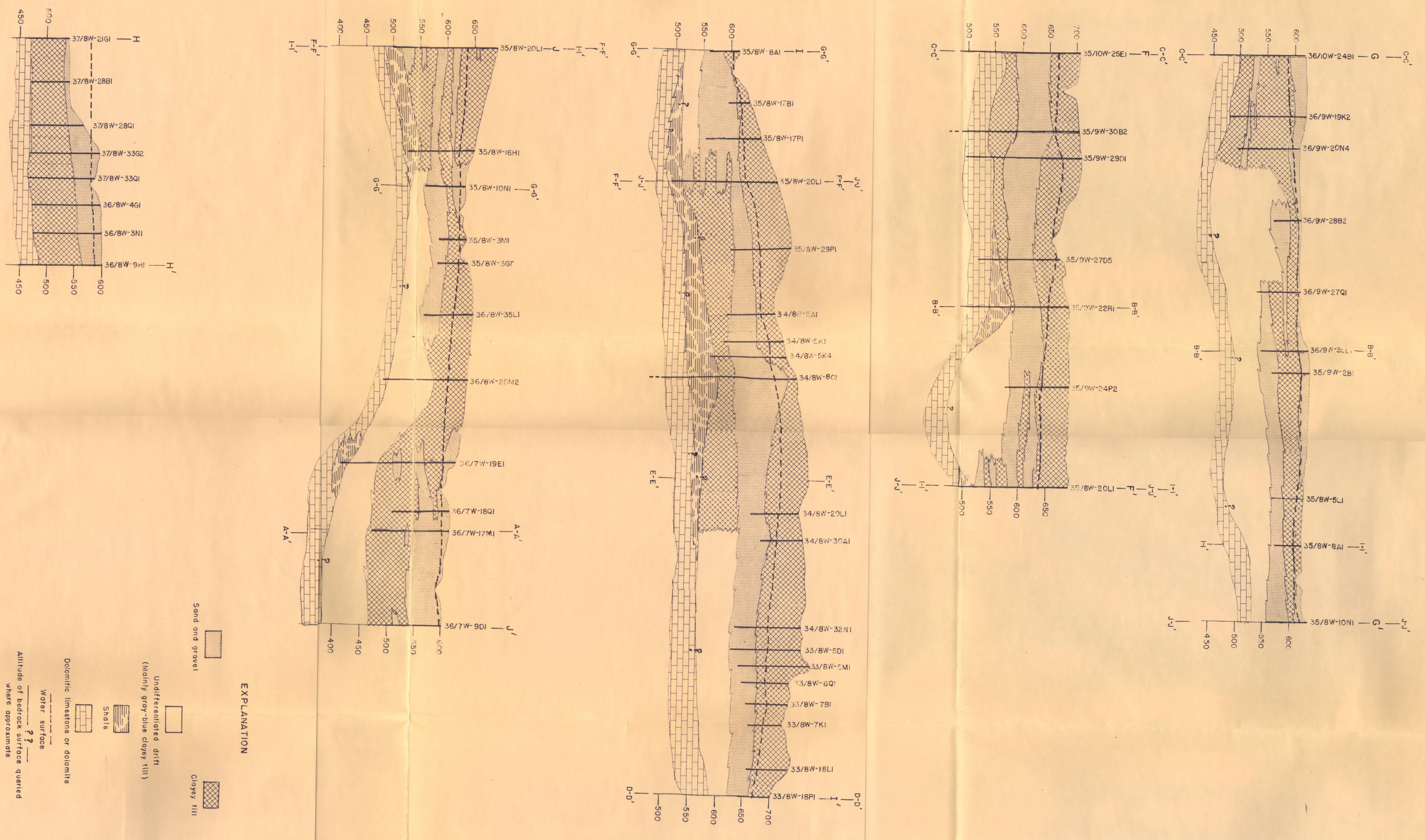

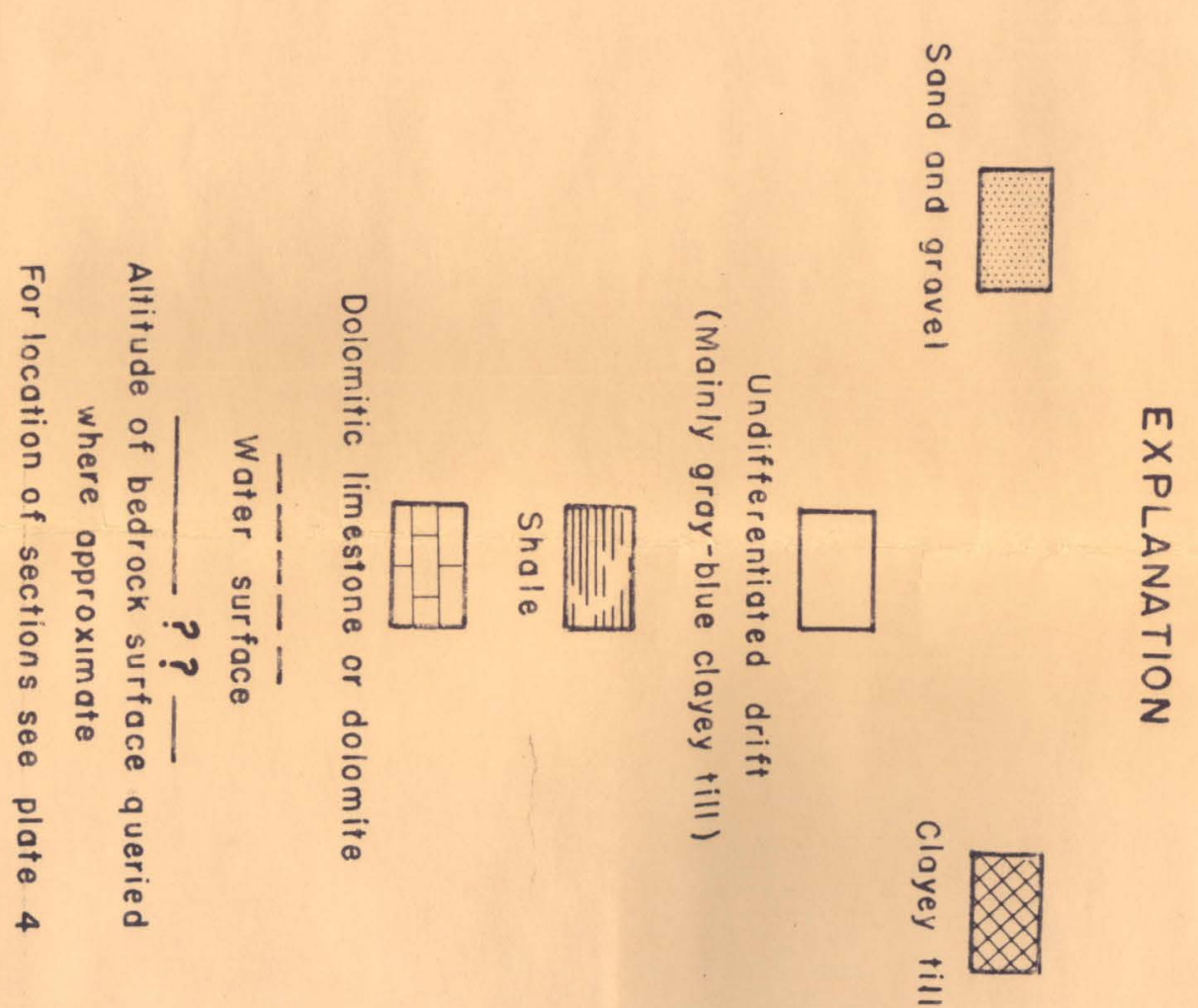




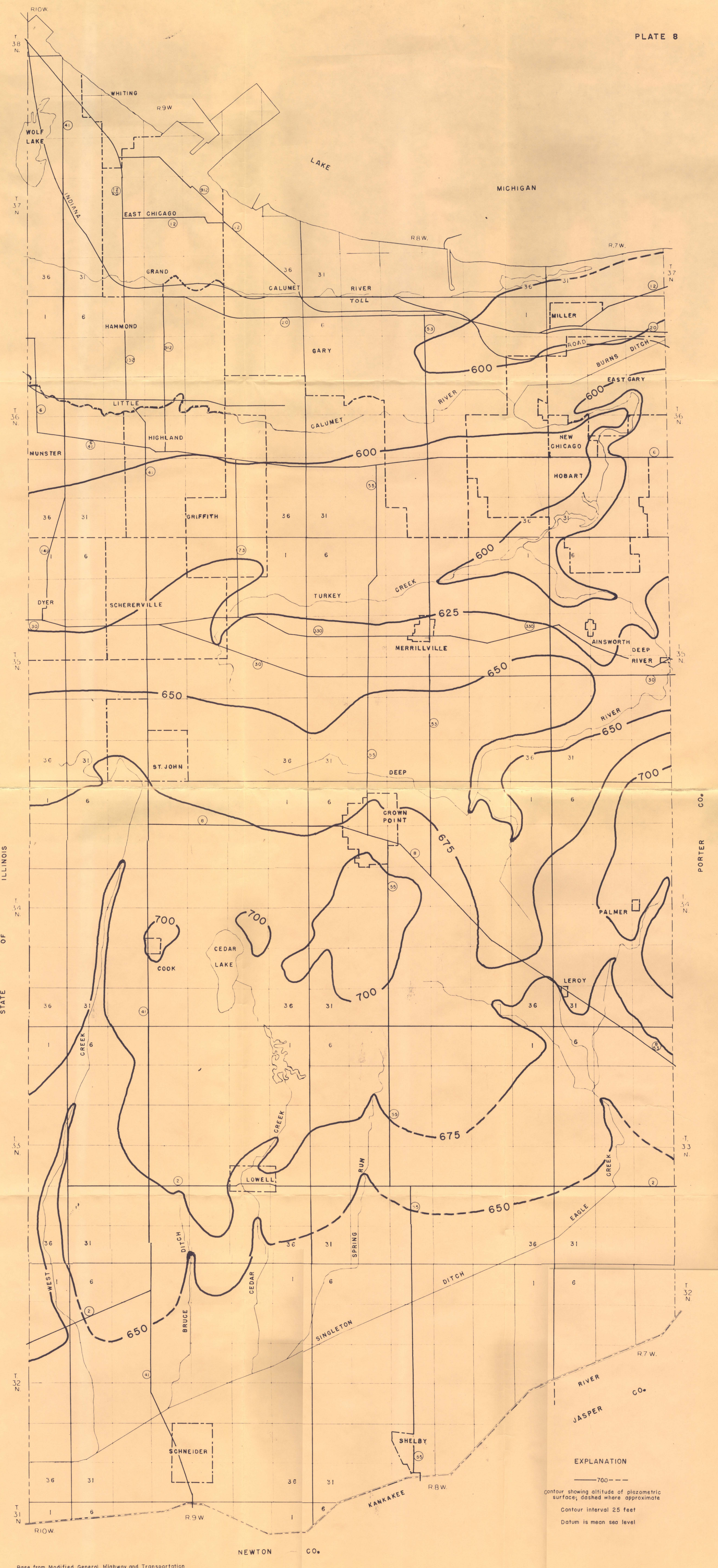

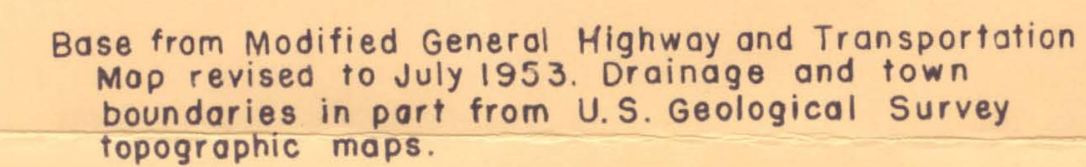

